\title{
DOSTRZEC I ZROZUMIEĆ. PORÓWNANIE WYBRANYCH METOD WIZUALIZACJI DANYCH ALS WYKORZYSTYWANYCH W ARCHEOLOGII
}

\author{
TO IDENTIFY AND UNDERSTAND. \\ A COMPARISON OF SELECTED ALS VISUALIZATION \\ TECHNIQUES USED IN ARCHAEOLOGICAL \\ INTERPRETATIVE MAPPING
}

\author{
Grzegorz Kiarszys \\ Katedra Archeologii, Uniwersytet Szczeciński, \\ ul. Krakowska 71-79, 71-017 Szczecin \\ Szczecin, Polska \\ Grzegorz.Kiarszys@usz.edu.pl \\ Łukasz Banaszek
}

Historic Environment ScotlandJohn Sinclair House, 16 Bernard Terrace Edinburgh, EH8 9NX, Wielka Brytania

lukasz.banaszek@hes.scot

\begin{abstract}
Application of airborne laser scanning (ALS) for archaeological purposes allows for identification of relief features. Unless the detection is automated, the recognition of archaeological objects in the observed dataset is bounded by the interaction between human mind, eye and visual phenomena that are displayed on the screen. To improve effectiveness of ALS interpretation several visualization techniques have been developed. However, due to their complexity the spatial information produced by these algorithms differs. The aim of the paper is to present the discrepancies between the most popular visualization techniques used for archaeological purposes. Unlike previous attempts, the presented comparison is based on the vector outputs of the interpretative mapping. Therefore, we demonstrate in detail the differences in the morphology as well as quantity of identified archaeological features due to the use of various visualization techniques.
\end{abstract}

KEYWORDS: archaeological prospection, airborne laser scanning, interpretation, visualization techniques, landscape archaeology 


\section{WSTĘP}

Świat, w którym żyjemy, jest konstytuowany za pomocą symboli i treści kulturowych. Do zrozumienia odbieranych przez nasze zmysły wrażeń niezbędna jest wiedza, za pomocą której porządkujemy uchwycone bodźce oraz nadajemy im sens. Bez niej rzeczywistość utraciłaby swoją logikę, przekształcając się w nieuporządkowany strumień doznań (np. Berkeley, 1709, s. 35; Hall, 1978, s. 100-101). Mechanizm ten jest obecny zarówno w życiu codziennym, w badaniach naukowych, jak i przy obcowaniu $\mathrm{z}$ dziełami sztuki. Uwidacznia się także $\mathrm{w}$ archeologii podczas interpretacji rozmaitych zobrazowań teledetekcyjnych oraz innych rodzajów dokumentacji (np. Rączkowski, 2004, 2012; Palmer, 2013, s. 76-77). Z tego samego powodu recepcja wszelkich wizualnych informacji jest podyktowana wiedzą interpretatora, jego wcześniejszymi doświadczeniami, a także np. towarzyszącymi mu emocjami oraz językiem, którym się posługuje (np. Barthes, 2008; Michalik, 2014). Według E. Husserla (za: Gosden, 1994, s. 104) postrzeganie świata jest zawsze intencjonalne i odwołuje się do konwencji kulturowych. $\mathrm{Z}$ tego powodu nie mniej istotny jest cel dokonywanej interpretacji oraz przyjęta perspektywa poznawcza. Kody znaczeniowe są kształtowane w określonych warunkach historycznych, co powoduje, że również wiedza wytwarzana za ich pośrednictwem ma historyczny charakter (Denbigh, 1979, s. 12), ugruntowany przez kontekst społeczny oraz relacje władzy (Foucault, 1980). W nauce ową wiedzę wstępną określa się często mianem teorii i jest ona nadrzędna w stosunku do procedury badawczej (np. Pałubicka, Tabaczyński, 1986, s. 78), choć w niektórych nurtach archeologii relacja ta jest nieco bardziej skomplikowana (np. Rączkowski, 2002). Uwidacznia się to szczególnie w różnych sposobach postrzegana roli empirii w procesie wytwarzania wiedzy o przeszłości oraz w strategiach krytyki stosowanych metod.

W niniejszym artykule zajmujemy się problematyką wykorzystywanych w archeologii metod wizualizacji numerycznych modeli terenu (NMT), wygenerowanych na podstawie danych pozyskanych za pomocą lotniczego skanowania laserowego (ALS). Omawiamy zagadnienia związane z analizą tych produktów, pochodnych skanowania, ich subiektywizmem i niejednoznacznością. Celem artykułu jest zatem ocena potencjału rozmaitych technik prezentacji modeli numerycznych przez porównanie rezultatów interpretacji przeprowadzonej dla każdego z wybranych sposobów przetwarzania danych z osobna.

Główną oś narracji stanowi relacja między wiedzą na temat lotniczego skanowania laserowego i zasad działania algorytmów wizualizacyjnych a rozumieniem obserwowanych fenomenów obecnych w generowanych zobrazowaniach. Nie odnosimy się natomiast do innego istotnego zagadnienia, jakim jest tworzenie narracji archeologicznej. By zachować przejrzystość argumentacji, omawiamy jedynie formalne cechy obiektów archeologicznych zarejestrowanych w analizowanych produktach ALS-u. Tym samym nie wychodzimy poza wstępny etap interpretacji (por. Banaszek, 2014). 
Niezautomatyzowana detekcja obiektów archeologicznych zarejestrowanych w danych ALS opiera się na wizualnej interakcji z produktami pochodnymi skanowania. Jednakże nie jest to jedyny etap opracowywania danych, w którym dochodzi do wzrokowego zaangażowania interpretatora. Zarówno klasyfikacja chmury punktów, jak i jej ewaluacja również wymagają świadomej obserwacji, bez której interesujące nas obiekty mogłyby zostać „wymazane” wskutek błędnego przypisania do jednej z klas (por. Banaszek, 2015, s. 56-57). Mimo to potencjał informacyjny danych zawartych $\mathrm{w}$ chmurze punktów oraz trudności związane $\mathrm{z}$ jej wizualną interpretacją nie stanowią przedmiotu zaawansowanych studiów. Ten podstawowy produkt skanowania skonstruowany jest z dyskretnych punktów i wykorzystuje się go do tworzenia modeli numerycznych charakteryzujących się ciągłością, a więc znacznie łatwiejszych w recepcji. Tym samym zaawansowane studia nad wizualizacją danych przestrzennych dla potrzeb archeologicznych mają na celu przetworzenie tych produktów pochodnych skanowania. Omawiane przez nas algorytmy zostały opracowane w celu „uwypuklenia” obecnej w NMT informacji o rzeźbie terenu, a także o obiektach posiadających formę krajobrazową, choć mogą być przydatne także w innych, niearcheologicznych aplikacjach.

Należy podkreślić, że kilka prac mających na celu porównanie różnych metod wizualizacji produktów pochodnych skanowania zostało już przeprowadzonych (Challis, Forlin, Kincey, 2011; Kokalj, Zakšek, Oštir, 2013; Bennett i in., 2012; Kokalj, Hesse, 2017). Ponadto wykorzystywane w archeologii rozmaite techniki graficznej prezentacji danych polskojęzycznemu odbiorcy przybliżył Ł. Banaszek (2015, s. 88-105). Przywołani badacze podkreślają brak idealnego rozwiązania. Różnorodność form terenowych i ich lokalizacja w odmiennych warunkach geomorfologicznych wymagają wykorzystania przynajmniej kilku metod jednocześnie. Choć różni archeolodzy mają swoje „ulubione” sposoby wizualizacji, a poszczególne metody przetworzenia danych uwypuklają bądź maskują w różnym stopniu wybrane formy terenowe (por. Kokalj, Hesse, 2017, s. 35), to wybór należy do każdego $\mathrm{z}$ interpretatorów z osobna. Stanowi on wypadkową pytań badawczych, jakości posiadanych danych, rodzaju obserwowanych obiektów archeologicznych oraz warunków środowiskowych.

Nie mamy na celu powielania osiągnięć powyższych porównań. Co istotne, w żadnym z przywoływanych przykładów nie analizuje się wyników interpretacji, a jedynie zestawia określone wizualizacje. Tym samym prezentowane w nich ilustracje mają niejako „mówić same za siebie”. Wskutek niedostatecznego przedstawienia interpretacyjnych pułapek niedoświadczony obserwator może się pogubić i wyciągnąć ze wspomnianych zestawień błędne wnioski. Wobec tego w niniejszym artykule zamiast prostego zestawienia zobrazowań ALS konfrontujemy rezultaty interpretacji dokonanej dla każdej wizualizacji z osobna. Należy jednocześnie podkreślić, że mimo najlepszych starań dokonane przez nas interpre- 
tacje do pewnego stopnia wpływały na siebie wzajemnie, choć z założenia były one dokonywane oddzielnie i staraliśmy się nie sugerować wcześniejszymi rezultatami. Wynika to z tego, że wiedza teoretyczna, dzięki której możliwa jest identyfikacja i kategoryzacja obiektów archeologicznych na zobrazowaniach ALS, poprzedza proces wizualnej interpretacji i nie da się przeprowadzić zaprezentowanych analiz, będąc jej pozbawionym. Każda interpretacja może mieć wpływ na zasób informacji i powodować, że „rozumienie” kolejnych analizowanych zobrazowań ALS będzie się zmieniało. Zmiany te mogą mieć bardzo subtelny charakter. Omówiony powyżej fenomen związany jest z mechanizmem „spirali hermeneutycznej" i poglądem, że interpretacja nie jest nigdy procesem skończonym ani neutralnym. Będąc tego świadomi, staraliśmy się odczytywać treści widoczne na produktach pochodnych skanowania w sposób wyizolowany. Ponadto omawiamy w szczegółowy sposób problemy związane z zastosowaniem konkretnej techniki prezentacji danych.

Z uwagi na wielość technik graficznej prezentacji danych ograniczyliśmy nasz wybór do kilku z nich. Porównujemy zatem wyniki interpretacji analizy cieniowania, zbliżonego do niej tzw. cieniowania z 16 kierunków, a także przetworzeń wygenerowanych za pomocą algorytmu Sky-view Factor - SVF (Kokalj, Zakšek, Oštir, 2011), Local Relief Model - LRM (Hesse, 2010) oraz Openness (Doneus, 2013), a także analizy głównych składowych - PCA (Devereux, Amable, Crow, 2008). Są to najpopularniejsze i najczęściej wykorzystywane dla celów archeologicznych wizualizacje, choć ich powszechność nie wynika wprost z potencjału danej techniki (patrz niżej). Część z nich, jak cieniowanie stoków, jest dostępna prawdopodobnie we wszystkich aplikacjach GIS-owych umożliwiających obserwację danych pod postacią graficzną. Pozostałe zostały zaczerpnięte $\mathrm{z}$ rozmaitych dziedzin nauki i twórczo włączone w zestaw narzędzi badawczych archeologii. Najczęściej wymagają one dedykowanego oprogramowania, dodatków/nakładek do popularnych programów GIS-owych lub własnej implementacji.

Aby osiągnąc zakładany cel, wykorzystujemy dane pochodzące z projektu Informatyczny System Ostony Kraju przed nadzwyczajnymi zagrożeniami (ISOK). Obszar położony nad rzeką Parsętą, w okolicach miejscowości Bardy, Świelubie i Skronie (gm. Dygowo, woj. zachodniopomorskie), został przez nas wyselekcjonowany jako „poligon doświadczalny” dla porównania rozmaitych metod wizualizacji (ryc. 1). Wybór ten wyniknął z tego, że jest to zwarta przestrzeń, urozmaicona pod względem topograficznym i geomorfologicznym, w której występują liczne przykłady obiektów archeologicznych. Są to pozostałości po różnorodnych działaniach człowieka w przeszłości, pochodzące z różnych epok i charakteryzujące się zróżnicowaniem form terenowych (np. Łosiński, 1957, 1973; Olczak, Siuchniński, 1970). Kontekst ten pozwolił nam ukazać przydatność omawianych metod wizualizacji danych przestrzennych i krytycznie ocenić ich potencjał informacyjny. 


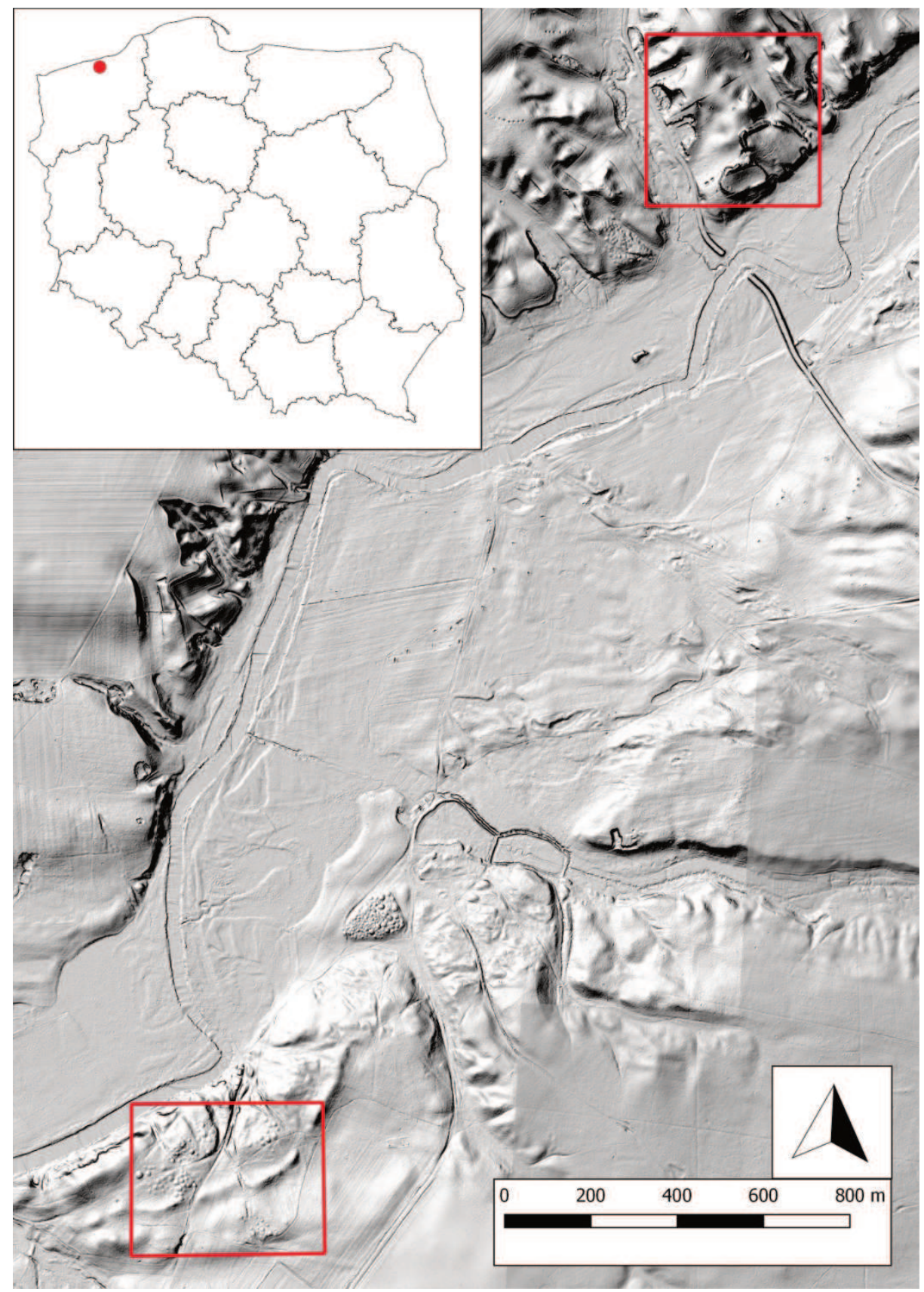

Ryc. 1. Lokalizacja obszaru badań. Kompozycja cieniowanego modelu terenu. Czerwone prostokąty wskazują miejsca poddane szczegółowej analizie (@ G. Kiarszys, Ł. Banaszek)

Fig. 1. Study area. Analytical hillshading. Red squares demarcate the areas of visual analysis presented in the paper (๑ G. Kiarszys, Ł. Banaszek) 


\section{ISOK. PUŁAPKA INTELEKTUALNA NA ARCHEOLOGÓW?}

Lotnicze skanowanie laserowe (ang. Airborne Laser Scanning) należy do grupy aktywnych metod teledetekcyjnych. ALS opiera się między innymi na technologii lidarowej, wskutek czego często bywa zamiennie nazywany lotniczym lidarem (por. Banaszek, 2015, s. 39-43). ALS pozwala na uzyskanie dużej liczby precyzyjnych pomiarów powierzchni ziemi oraz obiektów naziemnych (np. Cowley, Opitz, 2013, s. 1; Korzeniowska, Łącka, 2011, s. 271; Kraus, Pfeifer, 2001; Opitz, 2013, s. 13, 16-17; Wężyk, 2006, s. 120-121). Jednym z głównych zastosowań metody jest przewidywanie i modelowanie klęsk żywiołowych. Wykorzystuje się ją ponadto między innymi w celach planistycznych, gospodarczych oraz naukowych (np. gospodarka leśna i rolna, przemysł wydobywczy, zagospodarowanie terenu, badania atmosfery itd.) (por. Wężyk, 2014). Dzięki wysokiej precyzji ALS ma także duży potencjał $w$ rejestrowaniu niektórych typów obiektów archeologicznych znajdujących się zarówno na terenach otwartych, jak i pokrytych gęstą szatą roślinną. Historia wykorzystania lotniczych lidarów w studiach nad przeszłością sięga ostatniej dekady XX wieku (np. Crutchley, Crow, 2009, s. 3-4; Opitz, 2013, s. 14-15; Doneus, Kühteiber, 2013, s. 32-33; Banaszek, 2015, s. 66-69).

W polskiej archeologii ALS upowszechnił się w bardzo krótkim czasie głównie za sprawą realizacji projektu ISOK (por. Maślanka, Wężyk, 2014). Uzyskane dzięki niemu dane są udostępniane przez Centralny Ośrodek Dokumentacji Geodezyjnej i Kartograficznej ${ }^{1}$. Znajdujące się w centralnym zasobie produkty cyfrowe obejmują między innymi sklasyfikowane chmury punktów, numeryczne modele terenu, numeryczne modele pokrycia terenu (NMPT), warstwice oraz ortofotomapy (Kiarszys, Szalast, 2014). Wykorzystanie tych danych wymaga jednak umiejętności z zakresu obsługi programów GIS-owych i wiedzy o sposobach przetwarzania danych przestrzennych. $\mathrm{Z}$ tego powodu dużą popularnością wśród archeologów cieszą się geoportale (np. krajowy geoportal tworzony przez Główny Urząd Geodezji i Kartografii: http://mapy.geoportal.gov.pl/ czy portal Narodowego Instytutu Dziedzictwa: http://mapy.zabytek.gov.pl/nid/) udostępniające warstwy z cieniowanym modelem terenu i/lub mapami hipsometrycznymi. Jest to przydatne źródło wiedzy, które można porównywać z zamieszczonymi na owych geoportalach materiałami kartograficznymi, ortofotomapami oraz innymi danymi przestrzennymi. W ten sposób do zapoznania się z zasobem wystarczy jedynie podstawowa znajomość obsługi przeglądarki internetowej. Ponadto warstwy WMS/WMTS można zaimportować do własnych aplikacji GIS-owych, lecz wymaga to podstawowych umiejętności obsługi tychże. Pracując jedynie na wirtualnych warstwach, a przez to nie posiadając plików z danymi

\footnotetext{
${ }^{1}$ Istnieje możliwość bezpłatnego uzyskania produktów pochodzących z projektu ISOK między innymi dla celów naukowych, jeżeli wnioskodawca spełnia kryteria podane w art. 40a ust. 2 pkt 2 ustawy z dnia 17 maja 1989 r. Prawo geodezyjne i kartograficzne (Dz.U. z 2010 r. Nr 193, poz. 1287 z późn. zm.).
} 
(np. chmur punktów, NMT), nie istnieje jednak żadna możliwość manipulacji tymi źródłami, krytycznej ich oceny, uwypuklenia interesujących (z danego punktu widzenia) informacji ani zastosowania omawianych w niniejszym artykule metod wizualizacji.

Można zaryzykować stwierdzenie, że udostępnienie w internecie informacji o rzeźbie terenu uzyskanych za pomocą ALS-u do pewnego stopnia ukształtowało myślenie o lotniczym skanowaniu laserowym wśród archeologów, a sposób prezentacji jego rezultatów jest utożsamiany przede wszystkim z cieniowanymi modelami terenu (ang. analytical hillshading). Jest to zazwyczaj podstawowa, a często wręcz jedyna metoda wizualizacji danych lidarowych, po którą sięgają archeolodzy, ze względu na to, że omawiany algorytm jest zaimplementowany w niemal wszystkich programach GIS. Uzyskana za jego pomocą wizualizacja jest stosunkowo łatwa i na pozór intuicyjna $\mathrm{w}$ obserwacji, ponieważ przypomina pionową fotografię lotniczą wykonaną w odcieniach szarości, a wrażenie trójwymiarowości jest uzyskiwane dzięki światłocieniom (np. Kokalj, Zakšek, Oštir, 2013, s. 100). Posiada ona jednak szereg wad omawianych w dalszej części artykułu i opieranie interpretacji archeologicznej wyłącznie na podstawie cieniowania NMT powoduje liczne i istotne ograniczenia.

Intuicyjne podejście do danych ALS charakteryzowało pierwszą falę opracowań omawiających zastosowanie metody w badaniach archeologicznych i polscy badacze nie są w niej odosobnieni. Aplikacja lotniczego skanowania laserowego polegała, i często wciąż polega, na identyfikacji obiektów archeologicznych oraz opisie ich kształtów, rozmiarów, cech formalnych i ilościowych, a także lokalizacji (Doneus, Kühteiber, 2013, s. 32). Perspektywa archeologii kulturowo-historycznej, indukcyjne wnioskowanie i bezkrytyczne traktowanie danych lidarowych utrwalają takie podejście. W tym sensie ALS jest wykorzystywany przede wszystkim jako ,skuteczne narzędzie” do odnajdywania i ,kolekcjonowania” potencjalnych obiektów archeologicznych oraz ich precyzyjnego odwzorowania. Brak refleksji metodologicznej wpływa na sposób formułowania pytań badawczych oraz postrzeganie potencjału omawianej metody. Powoduje to, że mimo dostępności danych, model uprawiania archeologii niemal się nie zmienia. Pozytywistyczny schemat procedury badawczej i jej cele pozostają takie same, a różnica polega jedynie na zastosowaniu nowych narzędzi do ich realizacji.

Wizualna atrakcyjność i perswazyjność produktów pochodnych skanowania ugruntowuje błędny pogląd o tym, że wiedza teoretyczna nie jest potrzebna do zrozumienia cyfrowych zobrazowań obserwowanych na ekranie monitora. Jednak sama „,archeologiczna intuicja” nie wystarczy do wieloaspektowej analizy danych ALS. Nie dokonamy jej bowiem, jeśli nie będziemy posiadali wiedzy na temat obserwowanych fenomenów (Palmer, 2013, s. 77). Przetwarzanie i prezentacja danych z lotniczego skanowania laserowego składa się z wielu etapów, na których podejmowane są arbitralne decyzje wpływające na końcowy rezultat (por. Banaszek, 2014). Z tego powodu tak istotne jest zrozumienie procesu obróbki danych i mechanizmów działania wykorzystanych narzędzi. 


\section{PRODUKTY RASTROWE SKANOWANIA (CHARAKTER RASTRA, NMT/NMPT)}

Podstawowym produktem lotniczego skanowania laserowego, wytworzonym w rezultacie wstępnej obróbki danych, jest chmura punktów. Zawiera ona zbiór dyskretnych punktów, charakteryzujących się nieregularnym rozmieszczeniem, do których przypisane są określone atrybuty (więcej na ten temat np.: Kurczyński, 2014). Chmura punktów poddawana jest dalszej obróbce, polegającej na filtracji i klasyfikacji za pomocą wybranych algorytmów, a każdy z punktów zostaje przypisany do jednej z klas na podstawie posiadanych właściwości przestrzennych (topologicznych). Wykorzystywane w tym celu algorytmy różnią się zasadami działania i uzyskiwanymi rezultatami. Jeżeli obróbka danych jest realizowana świadomie, metodę filtracji i klasyfikacji dobiera się pod kątem celów badawczych, specyfiki terenu, z którego pochodzą przetwarzane pomiary, jakości danych wejściowych etc. $\mathrm{Na}$ tym etapie usuwane są także niektóre błędy pomiarowe lub przenosi się je do przeznaczonej dla nich klasy (np. Zakšek, Pfeifer, 2006; Haugerund, Harding, 2001; Kraus, Pfeifer, 1998), co ma istotne znaczenie również dla archeologii (por. Banaszek, 2015, s. 56).

Pochodną chmury punktów, którą wykorzystuje się powszechnie w archeologii, są numeryczne modele, przetworzone najczęściej do postaci rastrowej ${ }^{2}$. Posiadają one cechy, które ułatwiają ich prezentację wizualną i prowadzenie analiz. Są także „przyjazne" dla użytkownika ze względu na to, że mają charakter ciągły. Ponadto w numerycznych modelach nieregularnie rozłożone punkty są interpolowane do postaci regularnej siatki komórek posiadających identyczne rozmiary. Generowanie ciągłego obrazu rastrowego, będącego uporządkowanym zbiorem danych, uzyskuje się kosztem uśrednienia (generalizacji) wartości zapisanych w chmurze punktów (Kiarszys, Szalast, 2014, s. 276-277; Banaszek, 2015, s. 58-63). Należy tu nadmienić, że istnieje szereg algorytmów interpolacyjnych, które mogą się różnić uzyskiwanym rezultatem. Podobne trudności dotyczą określenia rozdzielczości rastra wynikowego. Najczęściej przyjmuje się, że wielkość komórek powinna być zbliżona do średniej odległości między punktami wykorzystanymi w interpolacji (s. 81).

Numeryczne modele reprezentują dane wysokościowe, ponieważ atrybutem poddanym interpolacji jest wartość wysokości przypisana do poszczególnych punktów (Gotlib, Iwaniak, Olszewski, 2007, s. 35-39). Do wygenerowania numerycznego modelu pokrycia terenu (NMPT, ang. digital surface model - DSM) tradycyjnie

\footnotetext{
${ }^{2}$ NMT może być także zaprezentowany pod postacią siatki nieregularnych trójkątów (ang. Triangulated Irregular Network - TIN). TIN w przeciwieństwie do modelu rastrowego jest formatem bezstratnym, ponieważ przechowuje dane o wszystkich punktach pomiarowych. Sąsiadujące ze sobą punkty pomiarowe stają się w tym modelu wierzchołkami sieci trójkątów, co pozwala na uzyskanie ciągłego obrazu (Crutchley, Crow, 2009, s. 8-11).
} 
wykorzystywane są punkty tzw. pierwszego echa (por. Borkowski, 2014), lecz stosuje się także bardziej zaawansowane rozwiązania (Khosravipour i in., 2015). Natomiast numeryczny model terenu (NMT, ang. digital terrain model - DTM) jest obliczany na podstawie punktów przypisanych do kategorii „grunt”. Powstaje on zatem po (przynajmniej częściowym) dokonaniu klasyfikacji obiektowej. Wytworzony w ten sposób model prezentuje rzeźbę terenu, po „usunięciu” obiektów naziemnych.

\section{WYKORZYSTANE TECHNIKI WIZUALIZACJI}

Omawiane przez nas zestawienie odnosi się do wyników interpretacji produktów pochodnych ALS-u pod kątem ich potencjału dla zastosowań archeologicznych. $\mathrm{Na}$ wstępie musimy jednak przedstawić w skrócie zestaw wybranych przez nas do porównania metod wizualizacji NMT i ich charakterystykę. Dzięki temu ilustrujemy występujące między nimi różnice oraz ich wpływ na rozbieżności obserwowane w uzyskiwanych rezultatach.

Ponadto $\mathrm{w}$ tym miejscu musimy podkreślić, że istnieją inne, nieomawiane w niniejszym artykule sposoby graficznej prezentacji danych lidarowych. Należą do nich m.in.: działania na wynikach zmultiplikowanej analizy cieniowania (Challis, Forlin, Kincey, 2011), pomiary nasłonecznia i radiacji (Yard i in., 2005; Robinson, 2006), rozmaite analizy stoków (Banaszek, 2015, s. 103-104), a także lokalnej i globalnej dostępności (Miller, 1994), wzmocnionego cieniowania (Rusinkiewicz, Burns, DeCarlo, 2006), MSII (Mara, Krömker, Breuckmann, 2010) czy zbiorczej widoczności (Hesse, 2016). Niektóre $\mathrm{z}$ tych technik pozwalają na znacznie więcej niż jedynie wyświetlenie danych, a ich wyniki mogą zostać użyte w modelowaniu przeszłej rzeczywistości (np. pomiary nasłonecznienia i zbiorczej widoczności).

\section{Analiza cieniowania}

W opinii wielu archeologów cieniowanie stoków stanowi podstawową technikę wizualizacji (Kokalj, Zakšek, Oštir, 2013, s. 100). Polega ona na wygenerowaniu wirtualnego źródła światła znajdującego się daleko poza analizowanym modelem (np. Yoëli, 1965; Phong, 1975; Horn, 1981; Blinn, 1977). Wyboru parametrów wysokości kątowej oraz azymutu naświetlania dokonuje analityk danych. Wskutek tego wszystkie piksele poddane są ,nasłonecznieniu” z tego samego kierunku.

Dzięki uzyskanej plastyczności analizowanego modelu numerycznego możliwa jest identyfikacja obiektów archeologicznych posiadających własną formę krajobrazową, a także rozpoznanie ich struktury (wkop lub nasyp). W tym sensie elementy 


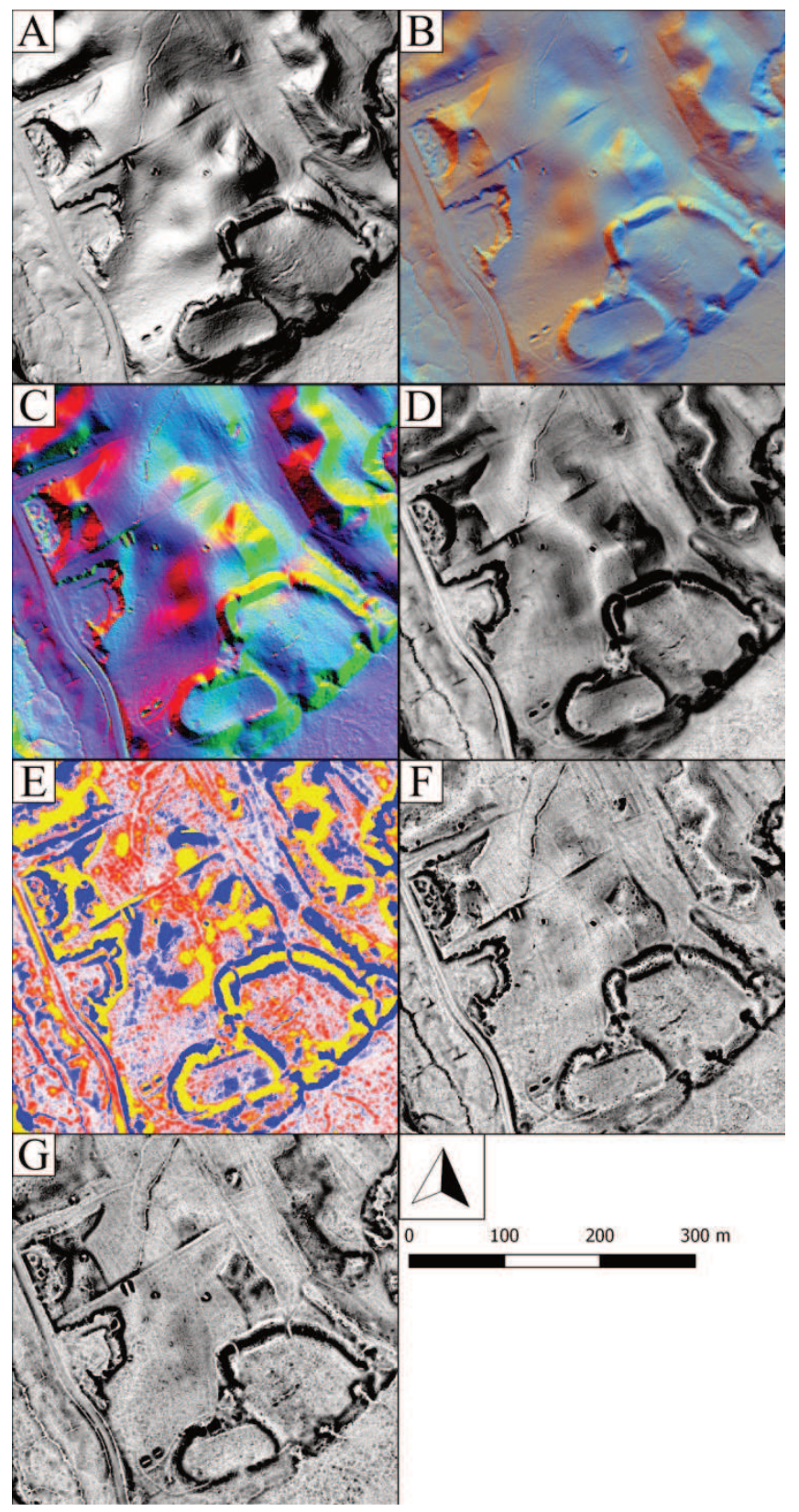

Ryc. 2. Zestawienie wizualizacji danych ALS dla obszaru A: A) Cieniowany model terenu; B) Analiza cieniowania z wielu kierunków; C) Analiza głównych składowych; D) Sky-view Factor; E) Local Relief Model; F) Analiza otwartości pozytywnej; G) Analiza otwartości negatywnej (@ G. Kiarszys, Ł. Banaszek) Fig. 2. ALS visualizations of area A: A) Analytical hillshading; B) Multiple-hillshading; C) Principal Component Analysis; D) Sky-view Factor; E) Local Relief Model; F) Openness Positive; G) Openness Negative (@ G. Kiarszys, Ł. Banaszek) 


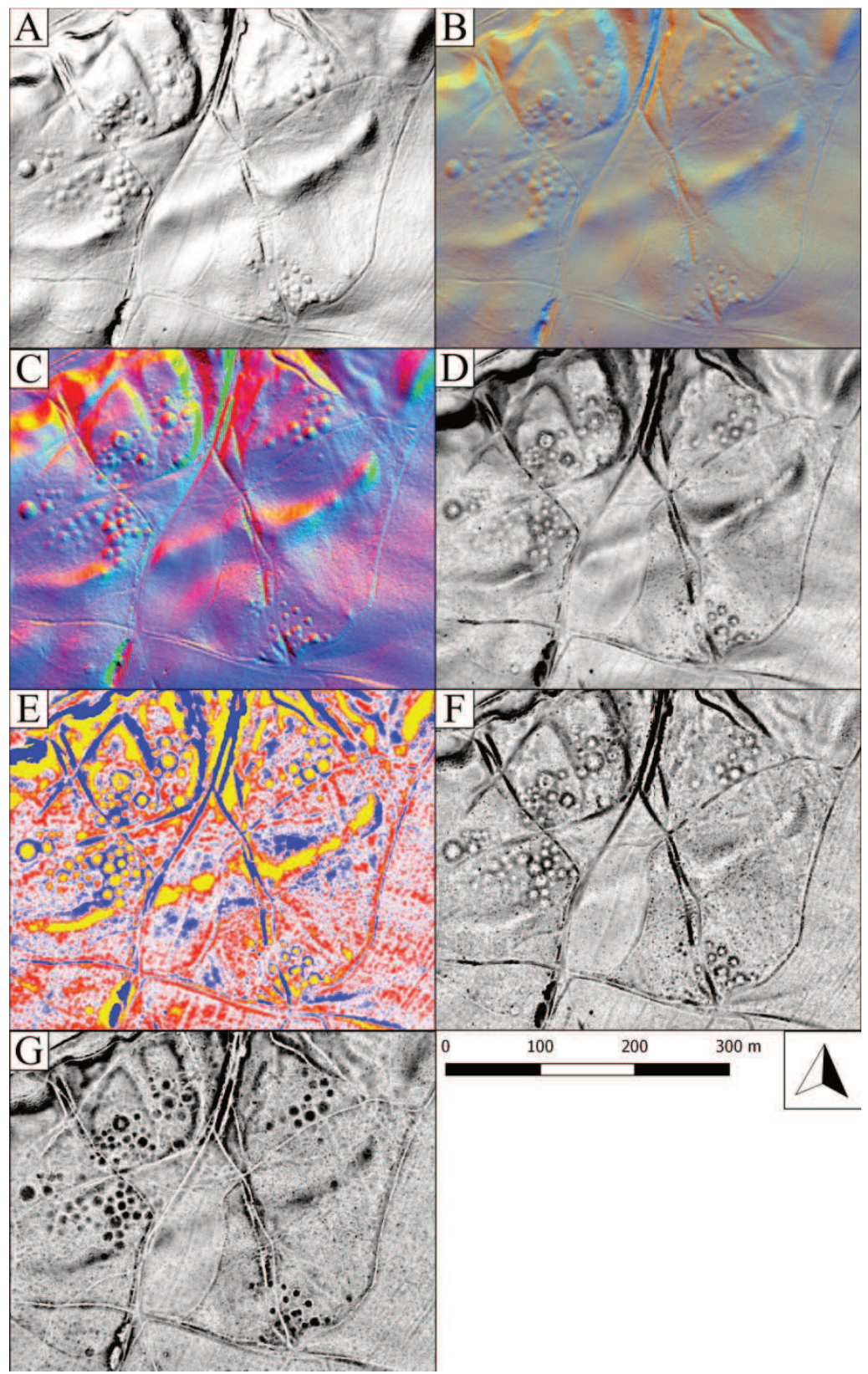

Ryc. 3. Zestawienie wizualizacji danych ALS dla obszaru B: A) Cieniowany model terenu; B) Analiza cieniowania z wielu kierunków; C) Analiza głównych składowych; D) Sky-view Factor; E) Local Relief Model; F) Analiza otwartości pozytywnej; G) Analiza otwartości negatywnej (@ G. Kiarszys, Ł. Banaszek)

Fig. 3. ALS visualizations of area B: A) Analytical hillshading; B) Multiple-hillshading; C) Principal Component Analysis; D) Sky-view Factor; E) Local Relief Model; F) Openness Positive; G) Openness Negative (○ G. Kiarszys, Ł. Banaszek) 
zorientowane prostopadle do kierunku nasłonecznienia są najbardziej wyraźne, podczas gdy zmniejszenie kąta pomiędzy promieniami wirtualnego światła a orientacją formy terenowej utrudnia obserwację. Równoległe ukierunkowanie struktury krajobrazowej względem źródła światła maskuje taki obiekt. Tym samym interpretacja archeologiczna oparta wyłącznie na pojedynczej wizualizacji cieniowania stoków jest ograniczona, ponieważ pewna grupa obiektów nie zostaje zidentyfikowana. Dotyczy to przede wszystkim obiektów liniowych (historyczne drogi, systemy pól i uprawy, umocnienia wojskowe itp.). Dopiero naświetlenie modelu numerycznego z innej strony pozwala na detekcję wcześniej „zakamuflowanych” form. Jednak w myśl tej zasady jednocześnie „zakrywane” są inne formy terenowe. Interpretacja obiektów archeologicznych charakteryzujących się skomplikowaną strukturą staje się wówczas utrudniona. Ponadto naświetlenie powoduje powstanie wirtualnego cienia, który również może skutecznie maskować niewielkie formy terenowe zlokalizowane na stokach. W konsekwencji widzimy, że oferowane przez wspomniane geoportale warstwy WMS/WMTS z cieniowanymi modelami terenu wygenerowanymi na podstawie danych z ISOK-a nie pozwalają na dostrzeżenie wielu obiektów archeologicznych (Banaszek i in., 2017). Brak możliwości przetworzenia tych danych należy zatem uznać za istotne ograniczenie, a podejście badawcze oparte wyłącznie na tym źródle jako niewystarczające.

\section{Cieniowanie z wielu kierunków}

Archeolodzy opracowujący produkty pochodne skanowania stosunkowo szybko zauważyli ograniczenia związane z cieniowaniem z jednego kierunku (Crutchley, 2006). Niektórzy badacze (np. Devereux, Amable, Crow, 2008, s. 471-472) sugerują, że dopiero szesnastokrotne przeprowadzenie cieniowania może dać odpowiednią ,pewność”, dzięki której większość obiektów archeologicznych zarejestrowanych w danych będzie mogła być rozpoznana. W konsekwencji komplikacje związane z powielaniem cieniowania przy jednoczesnej zmianie azymutu naświetlenia spowodowały, że doszło do opracowania metod pozwalających otrzymać produkty pochodne takiej techniki.

Wykorzystywana $\mathrm{w}$ archeologii analiza cieniowania z szesnastu kierunków polega na powieleniu tych obliczeń co $22,5^{\circ}$ azymutu. Otrzymane rezultaty przechowywane są w jednym pliku jako różne kanały tego samego zobrazowania. W konsekwencji poszczególne komponenty multiplikowanej analizy mogą być prezentowane jako osobne kanały palety barwnej. Różnice między lokalizacją cienia i obszarów naświetlonych na badanym obszarze odwzorowane są wówczas przy użyciu podstawowych kolorów: czerwonego, zielonego i niebieskiego. Mimo że obliczenia prowadzone są dla szesnastu kierunków, to wyświetlane na ekranie interpretatora zobrazowanie $w$ jednym czasie oferuje kompozycję jedynie trzech $\mathrm{z}$ nich. Jest to bardzo istotny czynnik, który jeżeli jest nieuświadomiony przez archeologa, może 
powodować jedynie intuicyjne, a przez to ograniczone wykorzystanie tej analizy. Standardowe ustawienie parametrów oferowane przez aplikacje GIS-owe powoduje, że jako kanał czerwony, zielony i niebieski wyświetlane są rezultaty naświetlenia z bliskich sobie azymutów (ich rozpiętość wynosi jedynie $45^{\circ}$, a zbiorczy kierunek zależy od oprogramowania wykorzystanego do obliczeń tej analizy). Zmiana wyświetlanych kanałów, a więc rozszerzenie kąta między poszczególnymi kierunkami naświetlania pozwala na uzyskanie większej plastyczności i eliminację aspektu przysłonięcia, charakterystycznego dla cieniowania. Jednocześnie zbyt duża rozpiętość może spowodować utrudnioną dla ludzkiego oka obserwację wskutek zbyt dużej różnorodności barw.

\section{Analiza głównych składowych}

Algorytm wykorzystywany w analizie głównych składowych (ang. Principal Component Analysis - PCA) operuje na cieniowaniu z szesnastu kierunków (Devereux, Amable, Crow, 2008). Dzięki jego użyciu możliwe jest otrzymanie produktu stanowiącego sekwencję zmultiplikowanych rezultatów naświetlania. Przetwarzane są rozbieżności między poszczególnymi analizami cieniowania, a takie opracowanie danych bazuje na „ruchu” wytworzonego ,cienia”, wynikającego ze zmiany azymutu promieni wirtualnego światła. Wyniki przechowywane są w jednym pliku jako odrębne kanały. W większości przypadków pierwsze trzy komponenty (wyniki działania) są odpowiednie dla interpretacji. Pozostałe zawierają zbyt wiele „szumów” (Devereux, Amable, Crow, 2008, s. 476). W konsekwencji, w zależności od wykorzystanego oprogramowania, są one często usuwane ze zobrazowań, co powoduje, że liczba kanałów rastra zostaje ograniczona do trzech. Mogą być one analizowane osobno lub w kombinacji RGB, zawierając nawet 99\% informacji oryginalnych szesnastu zobrazowań standardowej analizy cieniowania (Kokalj, Zakšek, Oštir, 2013, s. 105).

Na uzyskanych w ten sposób komponentach ujawniają się obiekty zorientowane w różne strony świata (co stanowiło problem w przypadku analizy cieniowania $\mathrm{z}$ jednego kierunku). Na otrzymanych wizualizacjach cieniowanie jest jednak zastosowane i nadaje ono plastyczność obserwowanym modelom. Należy także podkreślić, że bez znajomości lokalizacji źródła światła lub rozkładu kolorów (w przypadku kombinacji RGB) trudno jest rozróżnić, czy obserwowana struktura jest nasypem, czy wkopem. $\mathrm{Z}$ tego powodu istnieje konieczność analizy kilku komponentów lub ich zestawienia. Wyświetlenie wizualizacji jako barwnej kompozycji pierwszych trzech komponentów analizy PCA zupełnie „usuwa” efekt przesłonięcia wynikający z obecności cieniowania. Jednak z uwagi na dużą zmienność kolorów i nienaturalną paletę barw, takie zobrazowanie może być trudne w odbiorze. Dochodzi również do swoistego „przesunięcia” obserwowanych elementów rzeźby terenu (Bennett $\mathrm{i}$ in., 2012). 


\section{Sky-view Factor}

Analiza Sky-view Factor (SVF) polega na obliczeniu wartości „dostępnego” nieba (hemisfery powyżej wirtualnego horyzontu) dla każdego piksela w modelu numerycznym z osobna. Operuje ona na założeniu, że: (a) jasność hemisfery jest jednakowa w każdym jej punkcie; (b) nie istnieją dodatkowe źródła światła; (c) krzywizna Ziemi nie jest brana pod uwagę na małych dystansach (nie większych niż 10 km odległości) (Kokalj, Zakšek, Oštir, 2011). Dzięki tym obliczeniom generowane jest zobrazowanie ukazujące relacje topologiczne, w jakich znajduje się wybrany punkt (do określonego parametrami zasięgu - np. w promieniu od 1 do $12 \mathrm{~m}$ ). Jeżeli żadna przeszkoda nie zaburza widoczności nieba danemu pikselowi rastra (nie góruje nad nim) w obrębie zdefiniowanego zasięgu, to wartość „obserwowanej” hemisfery jest największa i wynosi „1”. Z kolei każdy element przysłaniający hemisferę powoduje spadek tej wartości. Tym samym obszary płaskie na wizualizacjach wyników tej analizy reprezentowane są przez jasne odcienie, nieregularności rzeźby terenu zaś uzyskują ciemniejsze tony. Jednocześnie z powodu prowadzenia obliczeń jedynie dla kątów powyżej wirtualnego horyzontu (generowanego osobno dla poszczególnych punktów w modelu numerycznym) formy wklęsłe (np. rowy, jamy) ujawniają się zdecydowanie lepiej niż wypukłe. Ograniczona dostępność dna takich form obiektów do hemisfery skutkuje osiągnięciem bardzo niskich wartości (bardzo ciemne fototony).

Rezultaty tej analizy są całkowicie pozbawione cieniowania (brak kierunkowego oświetlenia). Obszary ciemne na zobrazowaniach związane są wyłącznie z przyjętym rozciągnięciem kontrastu (z reguły regiony o wysokich wartościach są jasne). Oznacza to, że „duże” formy terenowe nie przysłaniają swoim cieniem tych mniejszych i możliwe jest prowadzenie jednoczesnego rozpoznania dla całości badanego obszaru (bez konieczności zmiany azymutu naświetlenia). W przypadku analizowania obszarów o dużych różnicach wysokości prospekcja jest utrudniona. Punkty leżące na stromych stokach są zdominowane przez te znajdujące się powyżej nich. $\mathrm{Z}$ tego powodu mają one niskie wartości. W celu uzyskania zobrazowania umożliwiającego wizualne doświadczenie tych miejsc należy zmienić ustawienia kontrastu. Prowadzi to jednak do wygładzenia różnicy barw właściwej obiektom archeologicznym (zazwyczaj ich deniwelacje i stromizny są mniejsze niż formy terenowe). Oznacza to, że ograniczone jest zastosowanie jednego typu zobrazowania dla obszarów o różnej elewacji i konieczne jest generowanie produktów „przystosowanych” do lokalnych warunków. Ponadto, z uwagi na brak punktowego źródła światła na podstawie korzystania wyłącznie z rezultatów analizy SVF, niemożliwe jest zrozumienie relacji wysokościowych w badanym terenie. Dotyczy to jednak wyłącznie dużych struktur geomorfologicznych. Ta informacja jest dostępna tylko za pomocą innych metod wizualizacji bądź pomiaru. 


\section{Local Relief Model}

Analiza Local Relief Model (LRM), podobnie jak obliczenia SVF, choć odnosi się do całości przetwarzanego modelu numerycznego, to wykonywana jest lokalnie, dla każdego miejsca na modelu numerycznym z osobna. Tym samym to nie „globalna” rzeźba terenu jest brana pod uwagę, lecz jej zróżnicowanie względem najbliższego sąsiedztwa. Zwrócenie uwagi na miejscowe różnice wysokości przy jednoczesnym odrzuceniu dużych form terenowych jest szczególnie ważne w przypadku prób rozpoznania obiektów archeologicznych. Elementy dziedzictwa zazwyczaj charakteryzują się niewielkimi rozmiarami w kontekście rozległych struktur geomorfologicznych. Dzięki wykorzystaniu filtra dolnoprzepustowego (ang. Low Pass Filter) (np. Reitberger, Krzystek, Stilla, 2008), a następnie działaniom na rastrach małe formy w analizowanym krajobrazie zostają ,,uwypuklone”. Rozległe struktury ulegają wówczas „spłaszczeniu” (do izolinii „,0”), pozostawione zostają jedynie miejscowe różnice rzeźby terenu. W opracowanej przez R. Hesse (2010) metodzie dochodzi również do generacji uśrednionego NMT, który pozwala na jeszcze bardziej plastyczne oddanie badanego obszaru. Algorytmy zaimplementowane w niektórych z dostępnych aplikacji nie uwzględniają tego etapu obróbki i w celu ich odróżnienia określa się je często uproszczonymi LRM (ang. Simplified LRM - SLRM).

Analiza LRM pozwala dostrzec zmiany w mikrorzeźbie terenu (możliwe do identyfikacji w obrębie określonego parametrami zasięgu). Ten sposób wizualizacji umożliwia jednoznacznie określić, czy obserwowany obiekt jest wklęsły, czy wypukły, co stanowi ważną informację dla interpretatora. Uzyskany produkt nie daje jednak żadnych wskazówek dotyczących ,globalnych” relacji topologicznych zachodzących na analizowanym obszarze.

\section{Analiza otwartości terenu - Openness}

W ramach tej techniki w obrębie założonego zasięgu i opierając się co najmniej na ośmiu profilach, dla każdego piksela obliczane są dwa kąty pionowe: jeden względem zenitu, drugi nadiru (Yokoyama, Shirasawa, Pike, 2002). Zwraca się zatem uwagę na maksymalne kąty, pod którymi sąsiadujący z punktem obliczeń wycinek powierzchni terenu (ograniczony zdefiniowanym zasięgiem) „przysłania” ten punkt. Jednocześnie działania te nie są ograniczone płaszczyzną horyzontu (w przeciwieństwie do SVF). Tym samym kąt pomiędzy punktem położonym w obrębie równej (gładkiej) powierzchni a jej profilem będzie taki sam, bez względu na to, czy jest to powierzchnia pozioma, czy przechylona (Doneus, 2013, s. 6435, ryc. 6). Jeżeli mamy do czynienia z punktem na szczycie stromego wyniesienia, to wartości kąta „przysłonięcia” względem zenitu są duże, podczas gdy względem nadiru niewielkie. Odwrotna sytuacja wiąże się z punktem zlokalizowanym na dnie wklęsłej 
formy. Średnia wartość wszystkich kątów względem zenitu (skalkulowana na podstawie rezultatów obliczeń na wszystkich profilach) stanowi pozytywną otwartość $\left(\mathrm{O}_{\mathrm{P}}\right.$, ang. positive openness $)$, uśrednienie zaś wartości kątów względem nadiru negatywną otwartość $\left(\mathrm{O}_{\mathrm{N}}\right.$, ang. negative openness $)$.

Wskutek nieuwzględnienia płaszczyzny horyzontu na wizualizacjach analizy otwartości niemożliwe jest pokazanie plastyczności dużych struktur geomorfologicznych. W zamian za to ukazywane są miejscowe relacje rzeźby terenu. Kompozycja rezultatów obliczeń pozytywnej i negatywnej otwartości pozwala na dostrzeżenie wielu cech obiektów archeologicznych zarówno w małej, jak i dużej skali (np. Doneus, 2013). Jednak w zależności od zastosowanego typu analizy (pozytywna/negatywna) odmienne aspekty form terenowych mogą zostać zidentyfikowane (patrz poniżej).

\section{METODYKA BADAŃ}

Pracę z danymi ALS rozpoczęliśmy od analizy pozyskanej z Centralnego Zasobu Geodezji i Kartografii chmury punktów w formacie .las (ryc. 4). Z wykorzystaniem oprogramowania LAStools dokonaliśmy ręcznej reklasyfikacji posiadanych danych, w miejscach, w których pierwotne ustalenia nie spełniały naszych oczekiwań. Następnie na podstawie punktów zebranych w klasie „grunt” wygenerowaliśmy model TIN, który poddaliśmy rasteryzacji, uzyskując numeryczny model terenu o rozmiarze komórki rastra $0,5 \times 0,5 \mathrm{~m}$. Model ten został później przetworzony za pomocą omówionych powyżej siedmiu algorytmów wizualizacyjnych.

Na kolejnym etapie wyznaczyliśmy dwa obszary przeznaczone do szczegółowej analizy. Ich zasięgi zdefiniowaliśmy z uwzględnieniem różnorodności form obiektów

Tabela 1. Zestawienie parametrów wykorzystanych wizualizacji

Table 1. Visualizations' parameters

\begin{tabular}{|l|c|c|c|c|c|c|}
\hline & \multicolumn{5}{|c|}{ Parametr } \\
\cline { 2 - 7 } & $\begin{array}{c}\text { Azymut } \\
\text { naświetlenia } \\
\text { (stopnie) }\end{array}$ & $\begin{array}{c}\text { Wysokość kąto- } \\
\text { wa źródła światła } \\
\text { (stopnie) }\end{array}$ & $\begin{array}{c}\text { Liczba } \\
\text { kompo- } \\
\text { nentów }\end{array}$ & $\begin{array}{c}\text { Liczba } \\
\text { kierun- } \\
\text { ków }\end{array}$ & $\begin{array}{c}\text { Zasięg } \\
\text { obliczeń } \\
(\mathrm{m})\end{array}$ & $\begin{array}{c}\text { Zasięg } \\
\text { filtra } \\
(\mathrm{m})\end{array}$ \\
\hline Cieniowanie stoków & 315 & 15 & & & & \\
\hline Cieniowanie z wielu kierunków & & 35 & & 16 & & \\
\hline PCA & & 35 & 3 & & & \\
\hline SVF & & & & 16 & 10 & \\
\hline LRM & & & & & 25 & 12 \\
\hline $\mathrm{O}_{\mathrm{P}}$ & & & & 16 & 10 & \\
\hline $\mathrm{O}_{\mathrm{N}}$ & & & & 16 & 10 & \\
\hline
\end{tabular}


archeologicznych występujących w ich obrębie. Na obszarze A znajdują się pozostałości wczesnośredniowiecznego grodu, zerodowane drogi i transzeje, jamy o nieznanej funkcji, relikty punktów umocnionych z czasów II wojny światowej oraz wyrobiska i kurhany. Na obszarze B zlokalizowane jest rozległe cmentarzysko kurhanowe składające się z obiektów o zróżnicowanej wielkości i kształcie, a także zerodowane drogi i nieliczne wkopy. Kolejne etapy postępowania odnosiły się wyłącznie do tych dwóch ograniczonych zon.

Następnie dokonana została interpretacja obiektów archeologicznych dostrzeżonych na kolejnych siedmiu wizualizacjach NMT (ryc. 4). Przeprowadziliśmy ją dla

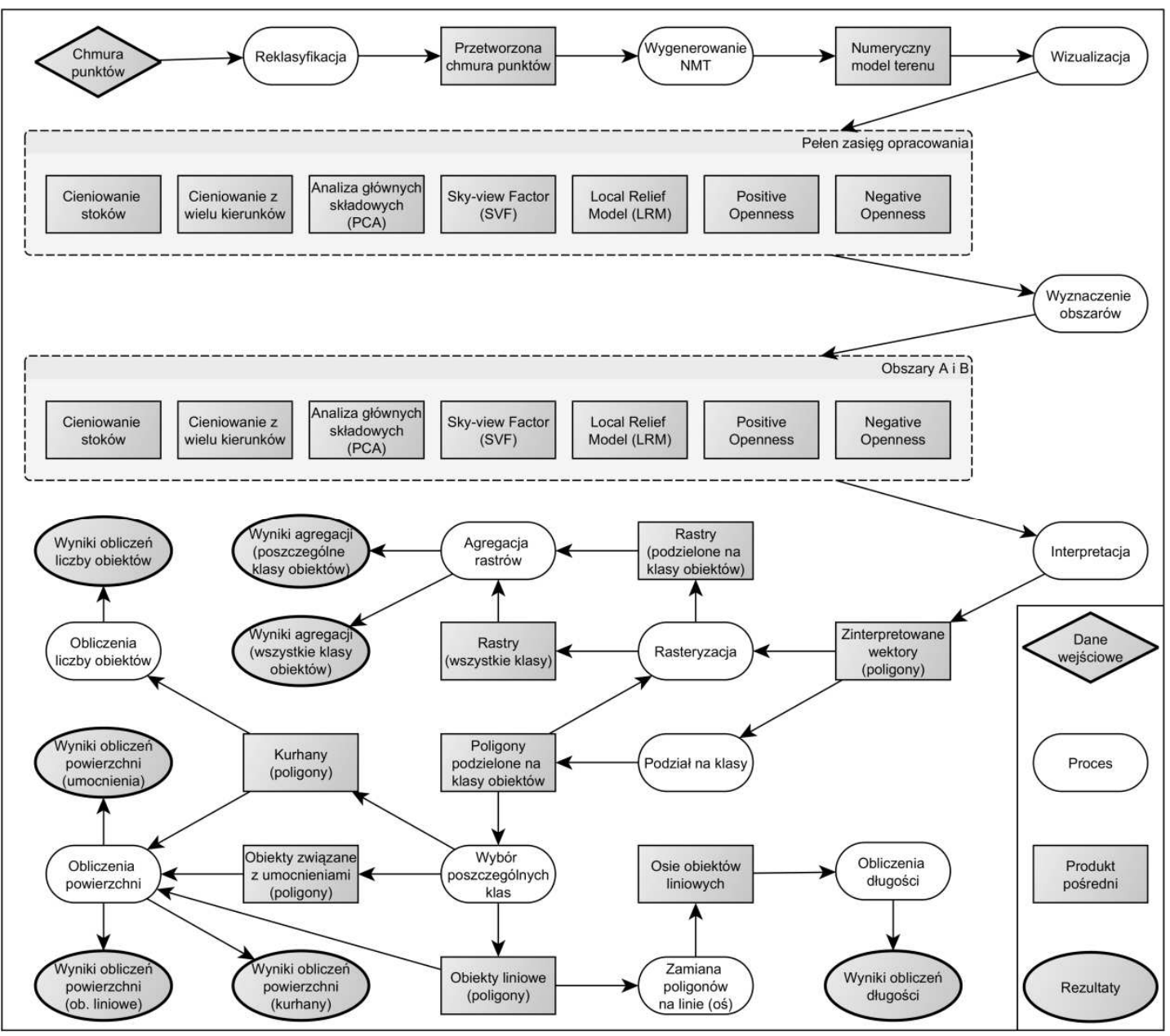

Ryc. 4. Schemat postępowania przyjęty w prezentowanych badaniach (C Ł. Banaszek)

Fig. 4. ALS data processing workflow chart (ㄷ Ł. Banaszek) 
każdego zasobu danych z osobna. Innymi słowy wyniki interpretacji, np. analizy cieniowania, nie zostały skopiowane z pozostałych wizualizacji. Mimo to nie można wykluczyć, że zaprezentowane interpretacje do pewnego stopnia wpływały na siebie, co omówiliśmy we wstępie tego artykułu, odwołując się do mechanizmu ,spirali hermeneutycznej".

Wraz z zakończeniem kartowania rozpoznanych obiektów archeologicznych (pod postacią poligonów) następowało przejście do kolejnego rastra. W rezultacie stworzyliśmy siedem warstw wektorowych reprezentujących zasób informacji o zabytkach ujawnionych na poszczególnych wizualizacjach. Zarówno powyższe, jak i kolejne etapy postępowania $\mathrm{z}$ danymi zostały przeprowadzone w środowisku QGIS.

Otrzymane wyniki posłużyły do celów porównawczych w pierwotnej formie wektorowej, jak i zrasteryzowanej. Porównanie rastrów odbyło się zarówno w odniesieniu do całości wyników czytania wizualizacji, jak i z podziałem na klasy obiektów. Porównanie wektorów zostało przeprowadzone wyłącznie na podstawie odseparowanych kategorii zinterpretowanych obiektów archeologicznych. Z uwagi na palimpsestowy charakter krajobrazu i nakładanie się na siebie poszczególnych reliktów przeszłej działalności człowieka, typy tych pozostałości zostały wyizolowane i przeznaczone do dalszej analizy.

Naszym celem nie była ocena wszystkich kategorii potencjalnych obiektów archeologicznych znajdujących się na analizowanym terenie, możliwych do rozpoznania dzięki analizie produktów pochodnych skanowania. Ewaluacja wpływu sposobu ujawniania się obiektów archeologicznych w poszczególnych wizualizacjach na ich recepcję przez interpretatora wymagała koherentnego zbioru danych porównawczych. Z tego powodu dalsze analizy zostały przeprowadzone na podstawie wybranych kategorii obiektów: 1 - nasypy (kurhany); 2 - obiekty liniowe (drogi i transzeje); 3 - obwałowania i fosy (relikty umocnień grodziska). Naszym zdaniem ich formalne (topologiczne) zróżnicowanie w wystarczający sposób reprezentuje skomplikowany charakter pozostałości po przeszłej działalności człowieka. Choć wybór ten jest ograniczony, to wybrane typy form terenowych umożliwiają szczegółowe omówienie różnych aspektów wpływających na sposób ujawniania się obiektów archeologicznych w omawianych wizualizacjach.

Rozbieżności między poszczególnymi kategoriami obiektów wymagały wypracowania odmiennego sposobu ich analizy (ryc. 4). Obiekty liniowe zostały zestawione pod względem ich długości (suma długości obliczona na podstawie wygenerowanych osi wyinterpretowanych poligonów). Miało to na celu identyfikację zauważalnych rozbieżności w sposobie ujawniania się obiektów liniowych w poszczególnych wizualizacjach. Jednocześnie wskutek tych różnic zrezygnowaliśmy z porównania powierzchni wszystkich obiektów tej kategorii, rozpoznanych na kolejnych zobrazowaniach. Formy widoczne na jednych wizualizacjach, a ,za- 
kryte" na pozostałych wpływałyby znacząco na rezultaty takiego zestawienia. Aby uniknąc tego problemu, do porównań powierzchni obiektów liniowych wybrany został jeden fragment transzei ujawniający się we wszystkich zobrazowaniach na obszarze A.

Obwałowania i fosy grodziska porównano na podstawie zajmowanej przez nie powierzchni. Kurhany natomiast zostały poddane analizie zarówno w odniesieniu do różnic w zinterpretowanej powierzchni, jak i liczby obiektów wyróżnionych na poszczególnych wizualizacjach ALS. Podobnie do analizy powierzchni obiektów liniowych, również w przypadku obliczeń powierzchni kurhanów wystąpił negatywny wpływ form ujawniających się jedynie w niektórych wizualizacjach. $\mathrm{Z}$ tego względu na potrzeby tego konkretnego porównania wyselekcjonowane zostały jedynie te nasypy, które powtarzały się w każdym ze zobrazowań. Ponadto uznaliśmy, że analiza obiektów liniowych oraz obwałowań i fos na podstawie liczby zinterpretowanych obiektów jest nieuprawomocniona. Ze względu na sieciowy charakter tych obiektów informacja opierająca się na liczbie wyrysowanych poligonów jest niejednoznaczna. O ile w odniesieniu do kurhanów wartość ta jest miarodajna, ponieważ indywidualne obiekty mają wyraźnie zaznaczone granice, to jeżeli chodzi o drogi, obwałowania i fosy jest ona zależna przede wszystkim od tego, jak obiekty te zostały zwektoryzowane przez interpretatora. Oznacza to, że np. krzyżujące się i nachodzące na siebie relikty dróg lub transzei mogły zostać skartowane w odmienny sposób.

\section{REZULTATY INTERPRETACJI I ICH KONFRONTACJA}

Wyniki uzyskane dzięki interpretacji i wektoryzacji poszczególnych zobrazowań zostały przedstawione z podziałem na dwa obszary (ryc. 5 i ryc. 6). Choć na podstawie obserwacji skartowanych rezultatów możliwe jest dostrzeżenie licznych różnic, to szczegółowa ocena rozbieżności jest trudna do przeprowadzenia. $\mathrm{Z}$ tego powodu dokonaliśmy rasteryzacji poligonów otrzymanych z wektoryzacji indywidualnych wizualizacji. W rezultacie powstało siedem nowych zobrazowań, w których każdy z pikseli miał wartość „,0" (oznaczającą brak obiektu archeologicznego) lub „1” (oznaczającą obecność antropogenicznej formy terenowej). Dzięki zastosowaniu kalkulatora rastrów wykonaliśmy następnie agregację tych danych, a jej wyniki zostały przedstawione graficznie (ryc. 7). Dzięki temu wyraźnie widać, że niektóre z obiektów archeologicznych zostały odnotowane jedynie na wybranych wizualizacjach, inne zaś na każdej z nich. Możliwe jest tym samym określenie stopnia powtarzalności danej informacji o formach antropogenicznych. Uwagę przykuwają również te obiekty, które zostały zidentyfikowane wyłącznie na jednym ze zobrazowań. Zostaną one omówione w dalszej części artykułu. 


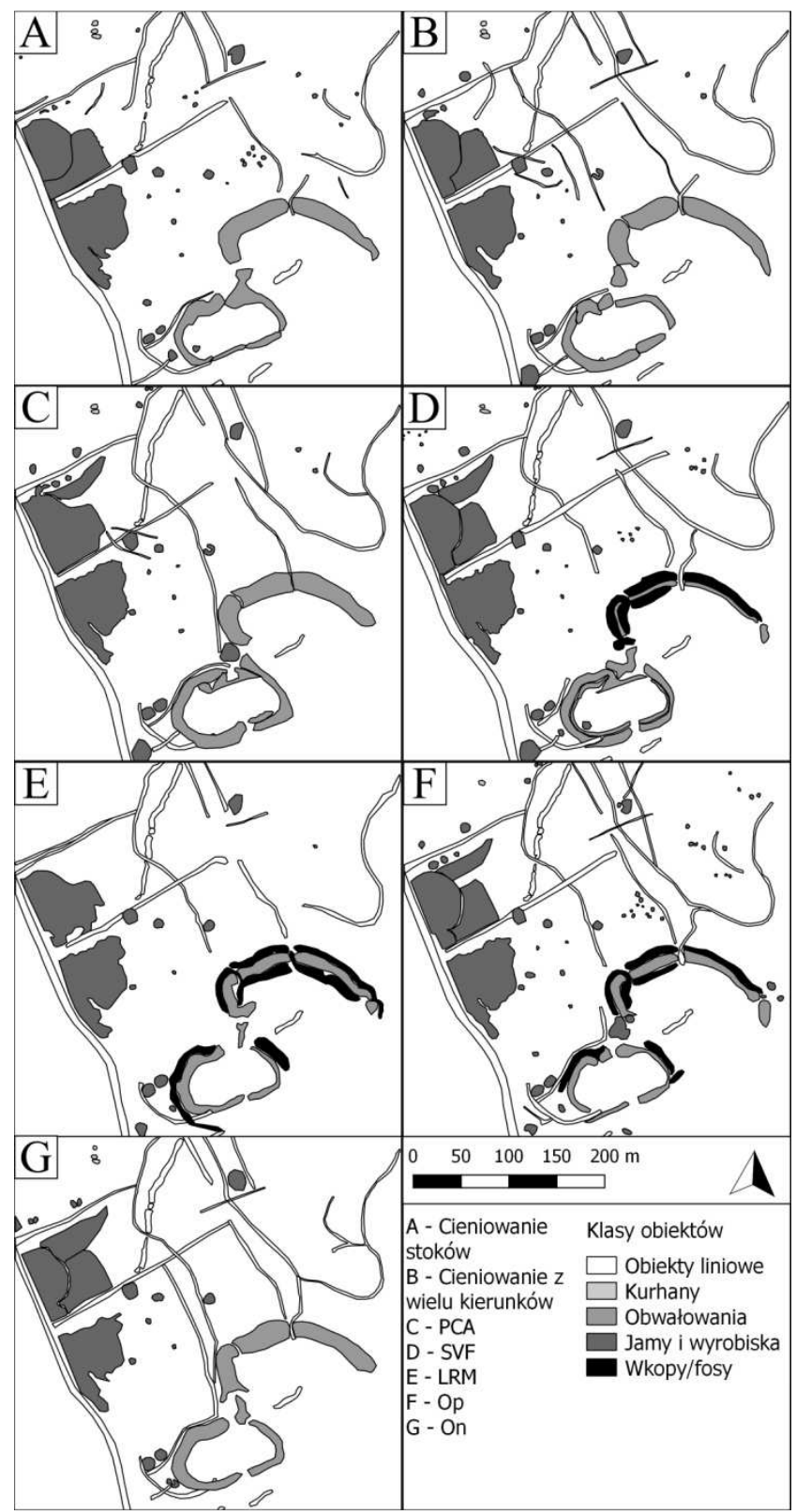

Ryc. 5. Zestawienie wyników interpretacji obiektów archeologicznych dla obszaru A: A) Cieniowany model terenu; B) Analiza cieniowania z wielu kierunków; C) Analiza głównych składowych; D) Skyview Factor; E) Local Relief Model; F) Analiza otwartości pozytywnej; G) Analiza otwartości negatywnej ( $\odot$ G. Kiarszys, Ł. Banaszek)

Fig. 5. The results of the interpretations of archaeological features identified within the area A: A) Analytical hillshading; B) Multiple-hillshading; C) Principal Component Analysis; D) Sky-view Factor;

E) Local Relief Model; F) Openness Positive; G) Openness Negative (@ G. Kiarszys, Ł. Banaszek) 


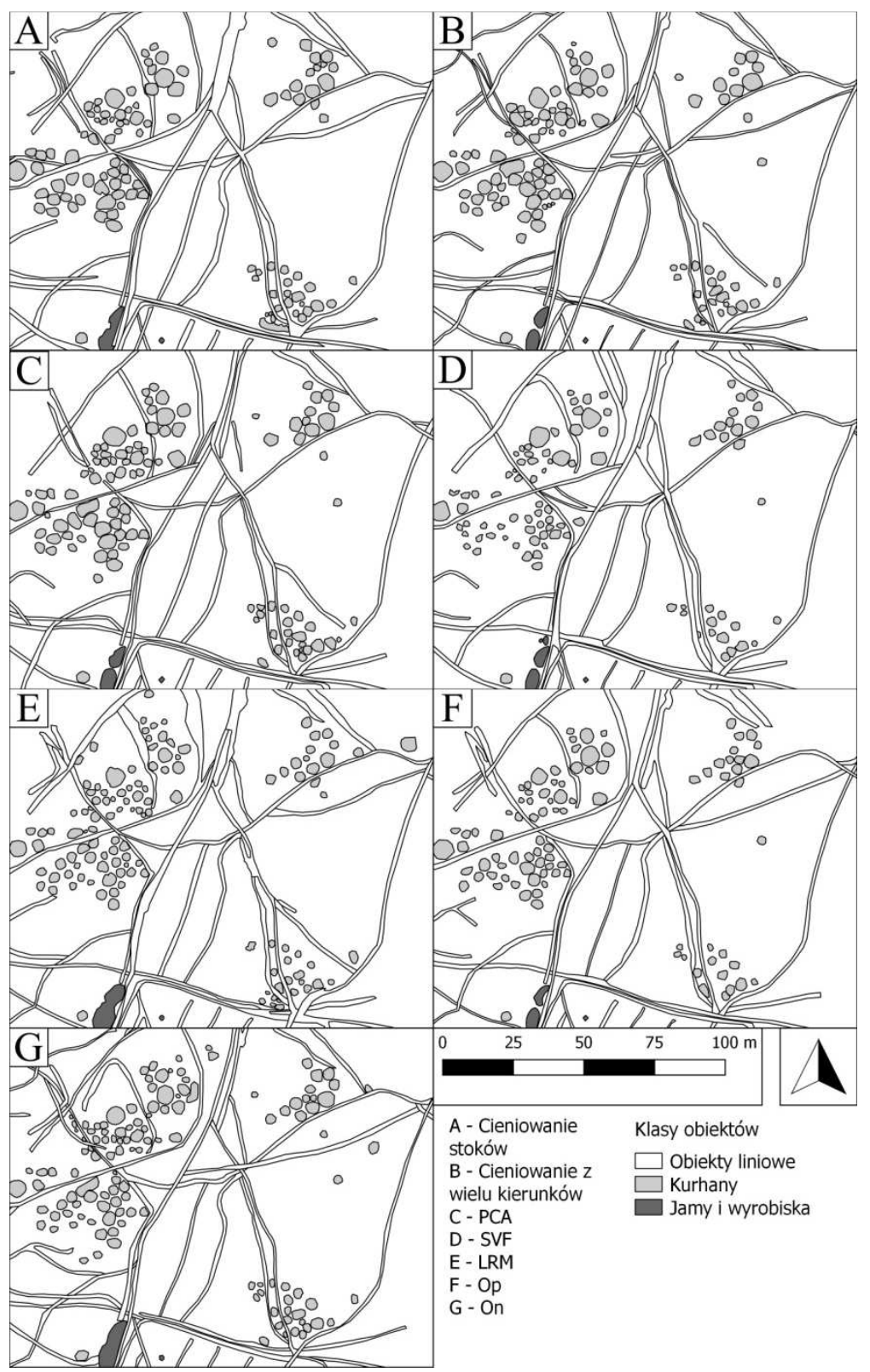

Ryc. 6. Zestawienie wyników interpretacji obiektów archeologicznych dla obszaru B: A) Cieniowany model terenu; B) Analiza cieniowania z wielu kierunków; C) Analiza głównych składowych; D) Skyview Factor; E) Local Relief Model; F) Analiza otwartości pozytywnej; G) Analiza otwartości negatywnej (@ G. Kiarszys, Ł. Banaszek)

Fig. 6. The results of the interpretations of archaeological features identified within the area B: A) Analytical hillshading; B) Multiple-hillshading; C) Priinciple Component Analysis; D) Sky-view Factor; E) Local Relief Model; F) Openness Positive; G) Openness Negative ( $\odot$ G. Kiarszys, Ł. Banaszek) 
Dzięki przeprowadzonej analizie można dostrzec „rozmycie” kształtów form obiektów, które rozpoznano w dwóch lub większej liczbie zobrazowań. Uwidoczniona w ten sposób zmiana przebiegu oraz szerokości takich obiektów jest godna uwagi. Zaproponowane podejście (oparte na zrasteryzowanych wynikach interpretacji) nie pozwala nam jednak wskazać różnic między konkretnymi wizualizacjami z osobna. Zbiorcze zestawienie (ryc. 7) powoduje swoistą ,,anonimowość” informacji z powodu utraty powiązania wyników interpretacji z rodzajem wizualizacji, na podstawie której owe rezultaty zostały wytworzone. Nie ma możliwości szczegółowej oceny wpływu zastosowania danego algorytmu na ujawnianie się obiektów archeologicznych.

$\mathrm{Z}$ tego powodu przeprowadziliśmy ilościowe porównanie wartości omówionych w paragrafie 4. Odnieśliśmy się do pomiarów powierzchni, długości oraz liczby wybranych wyinterpretowanych wektorów (tab. 2). Z przyczyn przedstawionych wyżej takie zestawienie objęło jedynie niektóre aspekty ujawniających się na wszystkich zobrazowaniach kurhanów (zlokalizowanych na obszarze B) oraz odcinka transzei (obszar A), a także pełnego zasobu (składającego się zarówno z tych form, które zidentyfikowano na siedmiu wizualizacjach, jak i tych widocznych tylko na niektórych z nich) obiektów liniowych oraz tych powiązanych z umocnieniami grodowymi (obszar A).

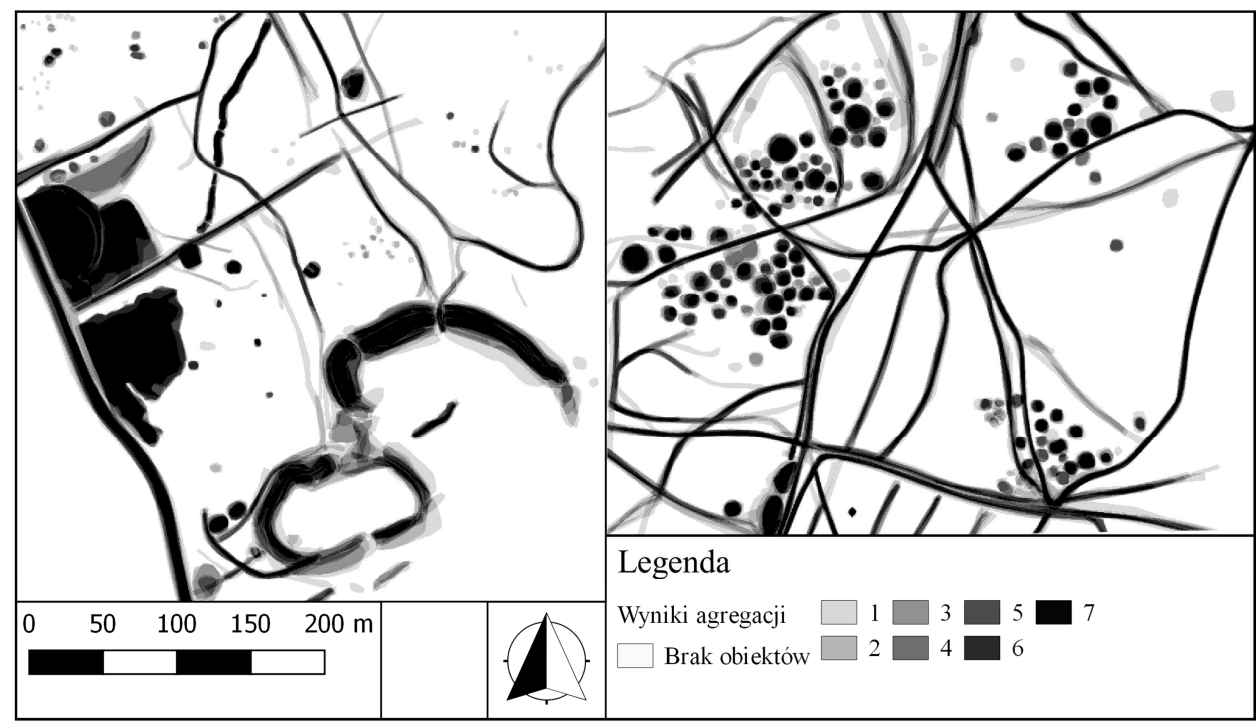

Ryc. 7. Zestawienie wyników agregacji zrasteryzowanych rezultatów interpretacji wszystkich analizowanych wizualizacji dla obszaru A (z lewej) i B (z prawej). Powtarzalność lub wyjątkowość informacji archeologicznej w kolejnych wizualizacjach została przedstawiona za pomocą odcieni szarości (C) G. Kiarszys, Ł. Banaszek)

Fig. 7. Combined and aggregated results of the rasterized archaeological features on different visualizations (Left: Area A; Right: Area B). The recurrence of archaeological features is presented by means of gray scale (C) G. Kiarszys, Ł. Banaszek) 
Tabela 2. Zestawienie wyników poszczególnych interpretacji (@ G. Kiarszys, Ł. Banaszek)

Table 2. Combination of the results of interpretations (○ G. Kiarszys, Ł. Banaszek)

\begin{tabular}{|c|c|c|c|c|c|c|c|c|}
\hline & & $\begin{array}{l}\text { Cieniowa- } \\
\text { nie stoków }\end{array}$ & $\begin{array}{c}\text { Cieniowanie } \\
\text { z wielu } \\
\text { kierunków }\end{array}$ & PCA & SVF & LRM & $\mathrm{O}_{\mathrm{P}}$ & $\mathrm{O}_{\mathrm{N}}$ \\
\hline & Powierzchnia transzei $\left(\mathrm{m}^{2}\right)$ & 550,33 & 530,42 & 656,73 & 621,96 & 663,78 & 642,01 & 738,71 \\
\hline & $\begin{array}{l}\text { Suma długości osi wszystkich } \\
\text { obiektów liniowych }(\mathrm{m})\end{array}$ & 2064,99 & 2685,13 & 2412,02 & 2224,21 & 1852,25 & 2447,54 & 2644,22 \\
\hline & $\begin{array}{l}\text { Liczba poligonów zinterpreto- } \\
\text { wanych jako obwałowania }\end{array}$ & 6 & 9 & 7 & 11 & 7 & 9 & 6 \\
\hline Obszar A & \begin{tabular}{|l}
$\begin{array}{l}\text { Suma powierzchni } \\
\text { obwałowań }\left(\mathrm{m}^{2}\right)\end{array}$ \\
\end{tabular} & 6033,72 & 6581,42 & 7515,15 & 4253,07 & 4216,29 & 3571,13 & 6523,69 \\
\hline & $\begin{array}{l}\text { Liczba poligonów zinterpreto- } \\
\text { wanych jako „rowy/fosy” }\end{array}$ & 0 & 0 & 0 & 4 & 6 & 7 & 0 \\
\hline & $\begin{array}{l}\text { Suma powierzchni obiektów zin- } \\
\text { terpretowanych jako „,rowy/fosy” } \\
\left(\mathrm{m}^{2}\right)\end{array}$ & 0 & 0 & 0 & 2466,08 & 3940,84 & 2520,64 & 0 \\
\hline & $\begin{array}{l}\text { Liczba zidentyfikowanych } \\
\text { kurhanów }\end{array}$ & 3 & 3 & 2 & 2 & 0 & 1 & 3 \\
\hline & $\begin{array}{l}\text { Liczba zidentyfikowanych kur- } \\
\text { hanów }\end{array}$ & 103 & 105 & 107 & 88 & 122 & 93 & 128 \\
\hline Obszar B & $\begin{array}{l}\text { Suma powierzchni kurhanów } \\
\text { rozpoznanych na wszystkich } \\
\text { wizualizacjach }\left(\mathrm{m}^{2}\right)\end{array}$ & 7057,31 & 6936,62 & 7343,23 & 4806,38 & 4908,61 & 5370,21 & 5855,58 \\
\hline & $\begin{array}{l}\text { Suma długości osi wszystkich } \\
\text { obiektów liniowych (m) }\end{array}$ & 5195,22 & 5415,64 & 4943,57 & 4609,45 & 4870,49 & 4836,38 & 5459,18 \\
\hline
\end{tabular}

\section{Porównanie powierzchni transzei}

Zlokalizowany w północnej części obszaru A fragment umocnień powiązanych prawdopodobnie z II wojną światową ujawniał się na wszystkich wizualizacjach. $\mathrm{Z}$ tego powodu możliwe było porównanie jego przebiegu (ryc. 8) oraz powierzchni zajmowanej przez poszczególne wyniki interpretacji (tab. 2). Na zdecydowanej większości zobrazowań transzeja została rozpoznana i zinterpretowana w kilku odcinkach (od 2 do 6). Przyczyną jednej z przerw była obecność drogi leśnej przecinającej ten obiekt, pozostałe nieciągłości są najprawdopodobniej powiązane z erozją, działalnością zwierząt i celowym zasypywaniem obiektu przez człowieka.

Obserwując kształt i przebieg rowu, można dostrzec, że na jednych zobrazowaniach obiekt ten jest stosunkowo szeroki (np. $\mathrm{O}_{\mathrm{N}}$, LRM, PCA), na innych zaś ujawnia się jako zdecydowanie zwężony (np. cieniowanie z wielu kierunków, cieniowanie stoków). Wartości powierzchni zajmowanej przez transzeję zostały przedstawione także graficznie (wykres 1). Skartowany zasięg okopu posiadał największą powierzchnię na interpretacji analizy negative openness. Najmniejszy poligon został 


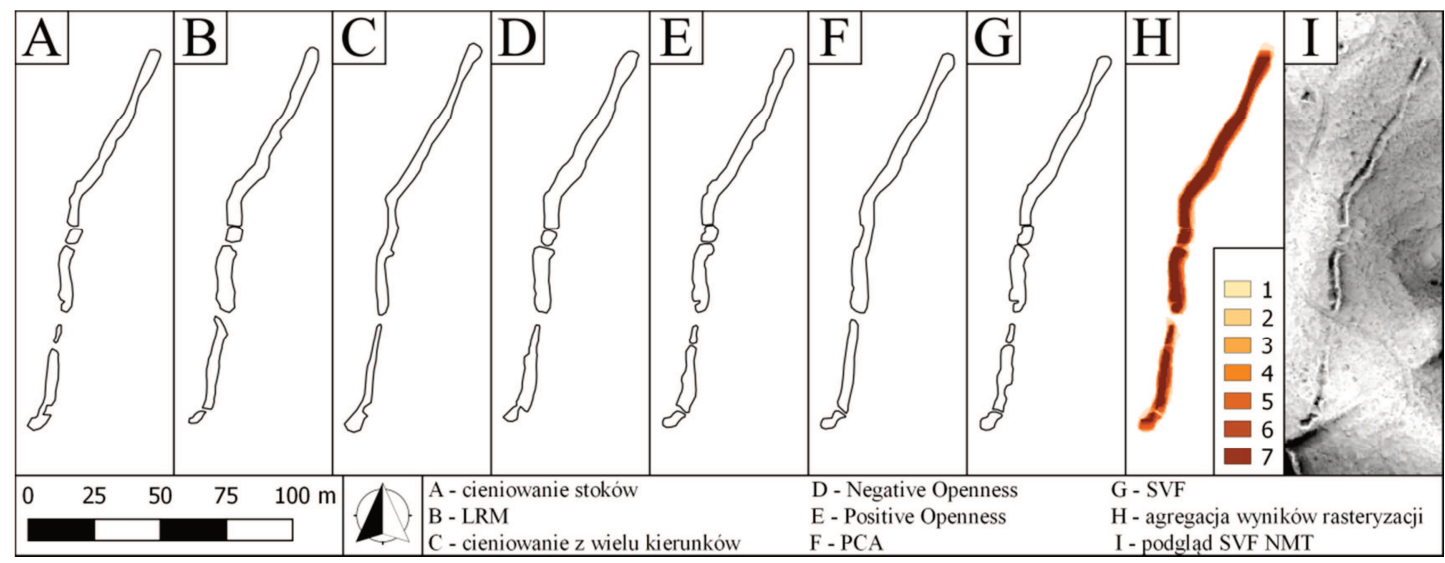

Ryc. 8. Zestawienie wyników interpretacji transzei położonej na obszarze: A) Cieniowany model terenu; B) Local Relief Model; C) Analiza cieniowania z wielu kierunków; D) Analiza otwartości negatywnej; E) Analiza otwartości pozytywnej; F) Analiza głównych składowych; G) Sky-view Factor; H) Agregacja wyników rasteryzacji; I) Wizualizacja SVF - podgląd (@ G. Kiarszys, Ł. Banaszek).

Fig. 8. Combination of the results of vectorization of a fragment of WWII trench from the area A, as seen on different visualizations: A) Analytical hillshading; B) Local Relief Model; C) Multiplehillshading; D) Openness Negative; E) Openness Positive; F) Principle Component Analysis; G) Skyview Factor; H) Aggregation of rasterized results of interpretation; I) SVF image (C G. Kiarszys, Ł. Banaszek)

Wykres 1. Porównanie pola powierzchni $\left(\mathrm{m}^{2}\right)$ zajmowanej przez transzeję na podstawie interpretacji odmiennych wizualizacji NMT

Chart 1. Comparison of the area $\left(\mathrm{m}^{2}\right)$ of WWII trench interpreted from 8 different ALS visualizations

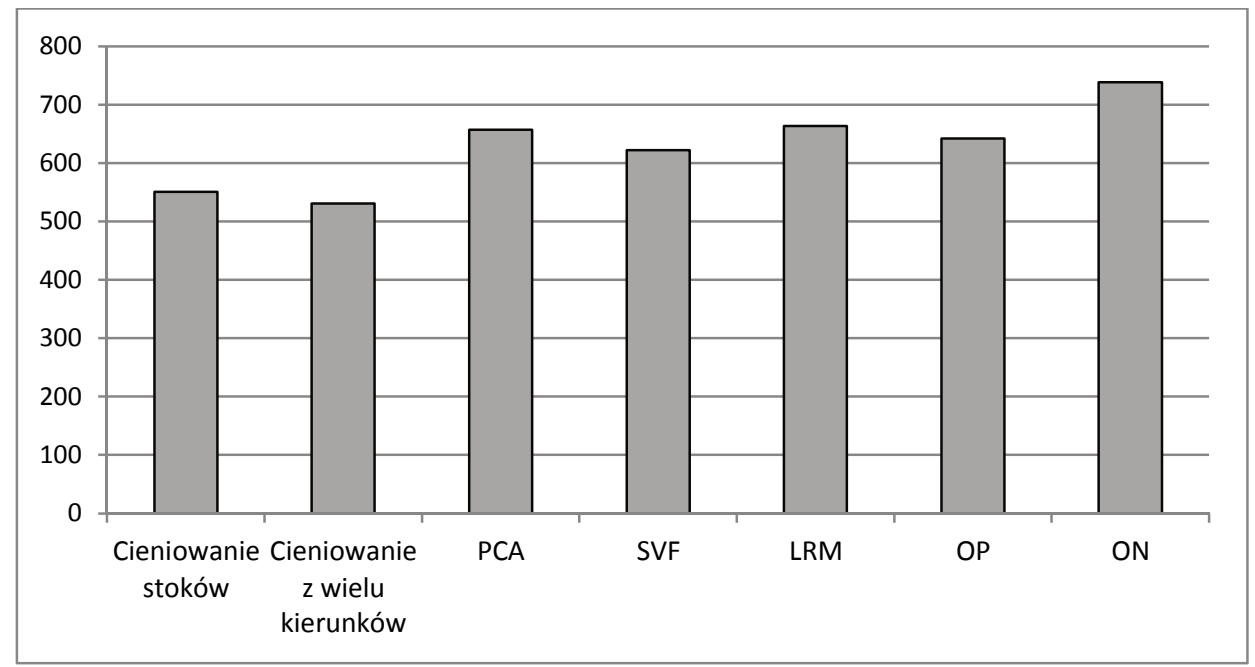


stał wygenerowany natomiast na podstawie cieniowania z wielu kierunków. Wyrysowany w ten sposób obiekt posiadał jedynie $71,8 \%$ powierzchni w porównaniu do interpretacji analizy negative openness. Te zaskakująco duże rozbieżności wynikają z odmiennego sposobu ujawniania się tego obiektu w różnych wizualizacjach. $\mathrm{W}$ rezultacie inne piksele są brane pod uwagę podczas kartowania. To swoista interakcja pomiędzy obszarami naświetlonymi i zacienionymi w dużym stopniu doprowadziła do zawężenia analizowanego obiektu. Na zwektoryzowanych interpretacjach analiz LRM, PCA, SVF, $\mathrm{O}_{\mathrm{P}}$ różnice w zmierzonym polu powierzchni transzei były stosunkowo niewielkie i mieściły się w przedziale od $1,1 \%$ do $6,3 \%$. W tej grupie najniższe wartości osiągnięto na podstawie algorytmu SVF, który co prawda najlepiej „radzi” sobie z liniowymi obiektami wklęsłymi i sam kształt transzei był na nim wyraźnie czytelny, natomiast towarzyszący jej niski nasyp ziemny powstały podczas jej kopania na przedpolu był słabo czytelny.

\section{Porównanie długości obiektów liniowych}

W poprzednim rozdziale argumentowaliśmy, że porównanie obiektów liniowych pod względem ich liczby nie było prawomocne. Rozbieżności w sposobie kartowania mogły powodować rozczłonkowanie lub agregację form przecinających się. Omówione wyżej różnice, które wynikają z obliczeń pola powierzchni transzei reprezentującej tę klasę obiektów w połączeniu z ujawnianiem się niektórych form o linearnym przebiegu wyłącznie w wybranych wizualizacjach, wykluczyły również zastosowanie takiego typu porównania dla większego obszaru badań. Z tego względu zdecydowaliśmy się na przeprowadzenie analizy długości obiektów linearnych. Jednak aby otrzymać tę wartość, najpierw musieliśmy przekonwertować wyniki interpretacji zapisane pod postacią poligonową na linie. W tym celu wygenerowane zostały osie poszczególnych poligonów, a następnie zsumowaliśmy ich długości (tab. 2).

Z uwagi na rozbieżne szerokości tych samych obiektów charakteryzujące wyniki interpretacji poszczególnych zobrazowań, sieć nałożonych na siebie osi (ryc. 9) nie ma jednolitego, identycznego przebiegu. Drobne przesunięcia rozmywają obserwowany obraz, jednak nie miały one istotnego wpływu na obliczenia długości tych linearnych form. Zestawienie wyników (wykres 2) pokazuje, że interpretacja cieniowania z wielu kierunków pozwoliła zidentyfikować największą liczbę (najdłuższą sieć) obiektów liniowych. Jedynie o 1,5\% niższy jest wynik uzyskany na podstawie obserwacji wizualizacji negatywnej otwartości NMT. Zatem możemy stwierdzić, że rozmiar sieci drogowej skartowanej wskutek interpretacji tych dwóch zobrazowań jest niemal identyczny. Z kolei najniższą wartość (stanowiącą jedynie $68,9 \%$ najwyższej) odnotowano w odniesieniu do wizualizacji LRM. Podobnie jak w przypadku transzei, należy podkreślić, że algorytm ten zdecydowanie lepiej oddaje 


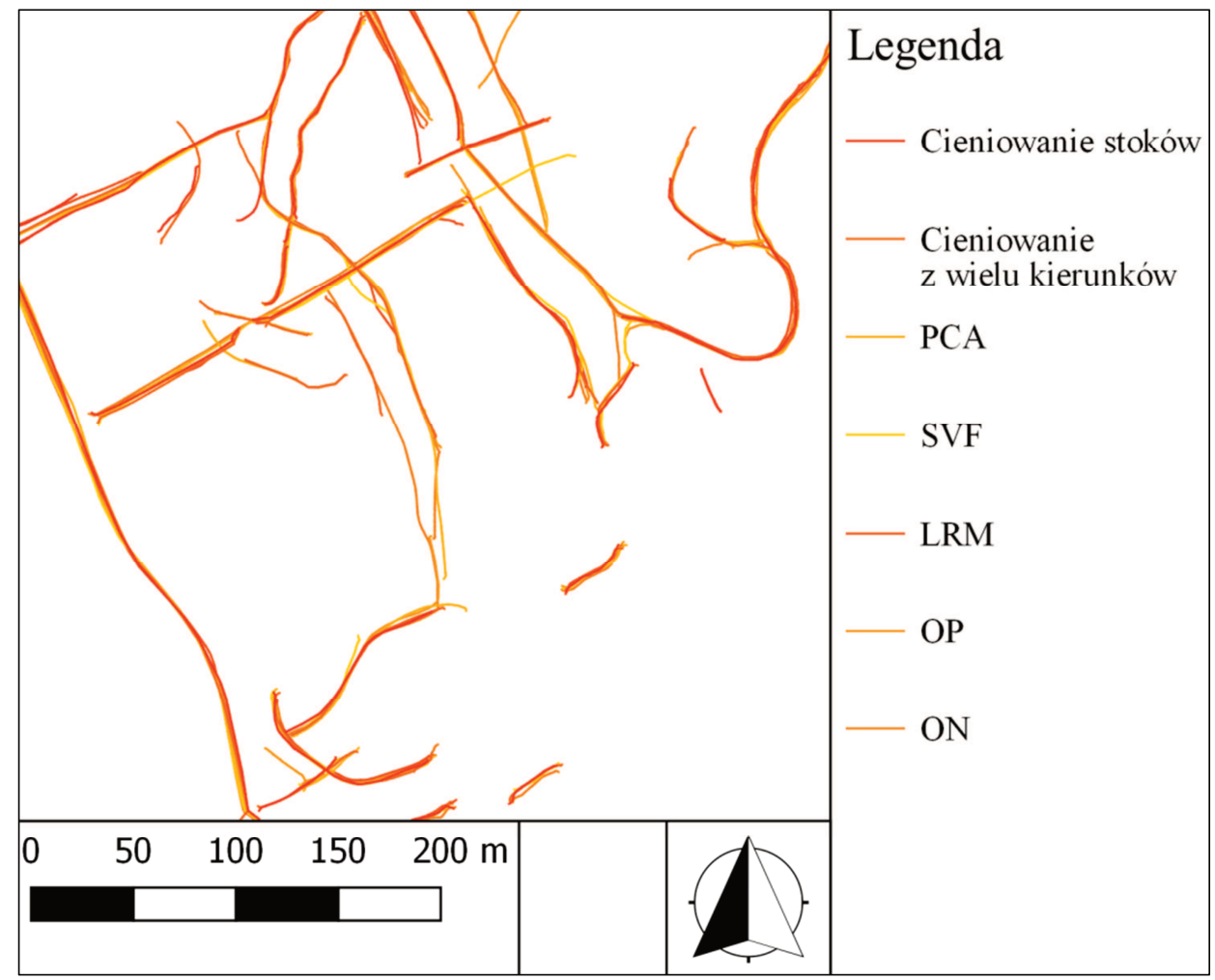

Ryc. 9. Przebieg osi obiektów liniowych na obszarze A (ㄷ G. Kiarszys, Ł. Banaszek)

Fig. 9. The linear features from the Area A (@ G. Kiarszys, Ł. Banaszek)

Wykres 2. Porównanie długości (m) osi obiektów liniowych na obszarze A wskutek interpretacji odmiennych wizualizacji NMT (C G. Kiarszys, Ł. Banaszek)

Chart 2. Comparison of linear features axis length $(\mathrm{m})$ from area A as measured on the different visualizations (C G. Kiarszys, Ł. Banaszek)

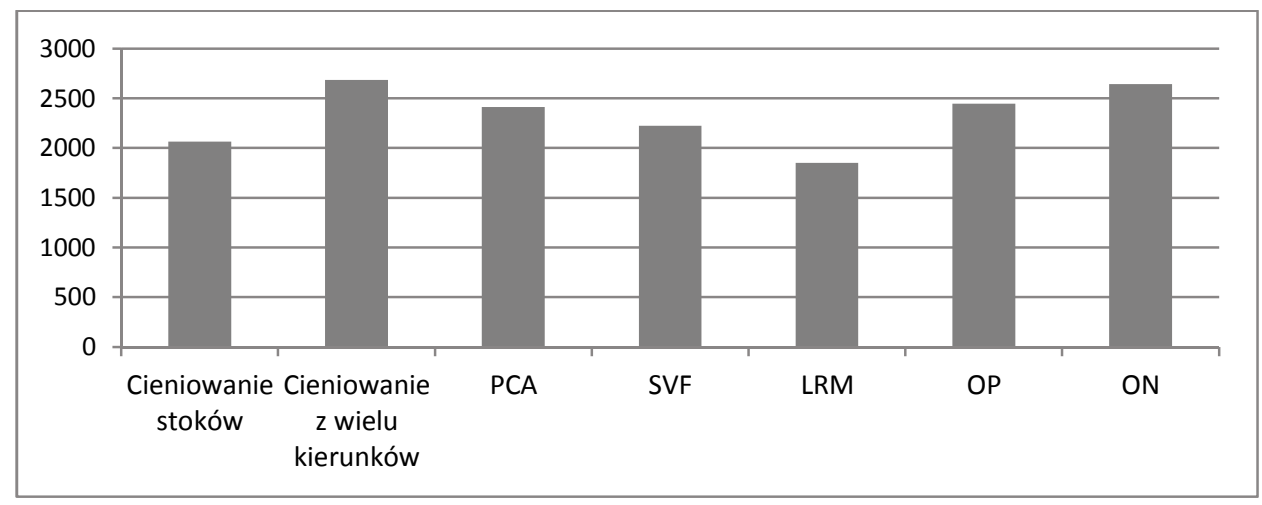


przebieg form wypukłych niż wklęsłych, zaś w zdecydowanej większości obserwowane formy linearne miały wgłębiony charakter. Podobne trudności z reprezentacją przez wizualizację LRM obiektów liniowych zostały odnotowane również we wcześniejszych porównaniach algorytmów wizualizacyjnych (por. Bennett i in., 2012, s. 46). Należy podkreślić, że $w$ tym przypadku część form linearnych położona na krawędziach większych struktur geomorfologicznych została przez nie przysłonięta (por. zestawienie dotyczące umocnień grodziska).

Niski wynik osiągnęliśmy także podczas interpretacji wyników analizy cieniowania stoków. W tym kontekście należy podkreślić brak możliwości zaobserwowania obiektów, których przebieg był równoległy do azymutu naświetlenia (ryc. 5). Choć nie stanowiły one dużego odsetka form linearnych, to niemożliwość ich dostrzeżenia znacząco wpłynęła na rezultaty obliczeń. Ponadto stosunkowo niski wynik interpretacji SVF należy łączyć z trudnościami ujawniania się płytkich form zlokalizowanych na stokach. W tym trudnym i pofałdowanym polodowcowym terenie zdecydowanie lepiej poradziły sobie pozostałe (mniej czułe na zmiany form terenowych) metody wizualizacji $\left(\mathrm{PCA}, \mathrm{O}_{\mathrm{P}}\right.$ i $\left.\mathrm{O}_{\mathrm{N}}\right)$.

Z powyższymi wynikami częściowo pokrywają się rezultaty analiz obiektów liniowych przeprowadzone na obszarze B. Podobnie jak w przypadku obszaru A największą sumaryczną długość dróg oddały analizy cieniowania z wielu kierunków oraz algorytm otwartości negatywnej. W tym przypadku jednak, odmiennie niż wcześniej, to pierwsza z wymienionych metod przyniosła wyższą wartość. Różnica między uzyskanymi rezultatami obu algorytmów dla obiektów liniowych wynosiła zaledwie $0,8 \%$. W przypadku pozostałych metod wizualizacji interpretacja wyników nie jest już tak jednoznaczna. Trzecią pod względem wartości sumę długości obiektów liniowych przyniosła interpretacja cieniowania stoków, która w analizie obszaru A znajdowała się na przedostatnim miejscu. Najmniejszą zmierzoną długość obiektów liniowych miała natomiast wizualizacja SVF. Wynosiła ona $84,4 \%$ największej wartości z analizy cieniowania. Należy też zaznaczyć, że wyniki pomiarów uzyskane z algorytmów PCA, LRM oraz $\mathrm{O}_{\mathrm{P}}$ cechowały się dużym podobieństwem, a różnice między nimi mieściły się w przedziale od 1,5\% do 2,2\%. Analiza obszaru B pod kątem sumarycznej długości obiektów liniowych prowadzi do wniosku, że niektóre z wykorzystywanych metod wizualizacji NMT $\left(\mathrm{MH}, \mathrm{O}_{\mathrm{N}}\right)$ są mniej ,wrażliwe” na lokalne warunki terenowe i mogą dostarczyć bardzo podobnych rezultatów, podczas gdy skuteczność pozostałych algorytmów może się zmieniać w zależności od ukształtowania terenu, charakterystyki obiektów liniowych czy ich ułożenia względem wirtualnego źródła światła.

\section{Porównanie obiektów zinterpretowanych jako umocnienia grodziska}

Umocnienia wczesnośredniowiecznego grodziska znajdującego się na obszarze A ujawniają się na wszystkich wykorzystanych wizualizacjach danych ALS (ryc. 5). $\mathrm{Na}$ trzech $\mathrm{z}$ nich $\left(\mathrm{O}_{\mathrm{P}}, \mathrm{LRM}\right.$ i SVF) zidentyfikowany i skartowany został zasięg 
obiektów, które na pierwszy rzut oka mogłyby być zidentyfikowane jako potencjalna niecka fosy. Porównanie łącznej wartości powierzchni obwałowań zinterpretowanych na podstawie różnych zobrazowań wskazuje na istotne rozbieżności między uzyskanymi wynikami (tab. 2 i wykres 3). Powierzchnia obwałowań zmierzona na podstawie $\mathrm{O}_{\mathrm{P}}$ wynosi tylko $47,5 \%$ maksymalnej powierzchni zinterpretowanej za pomocą analizy PCA. Różnice te wynikają ze sposobu, w jaki obiekty wypukłe (podłużne nasypy) są odwzorowywane przez poszczególne metody wizualizacji. PCA charakteryzuje się największą zmierzoną wartością ponieważ, jak wspomniano wcześniej, mamy do czynienia z rastrem przedstawiającym wartości trzech różnych

Wykres 3. Porównanie pola powierzchni $\left(\mathrm{m}^{2}\right)$ zajmowanej przez umocnienia grodziska wskutek interpretacji odmiennych wizualizacji NMT (C G. Kiarszys, Ł. Banaszek)

Chart 3. Comparison of the rampart and moat of the early medieval stronghold area $\left(\mathrm{m}^{2}\right)$ interpreted from 8 different ALS visualizations (C G. Kiarszys, Ł. Banaszek)

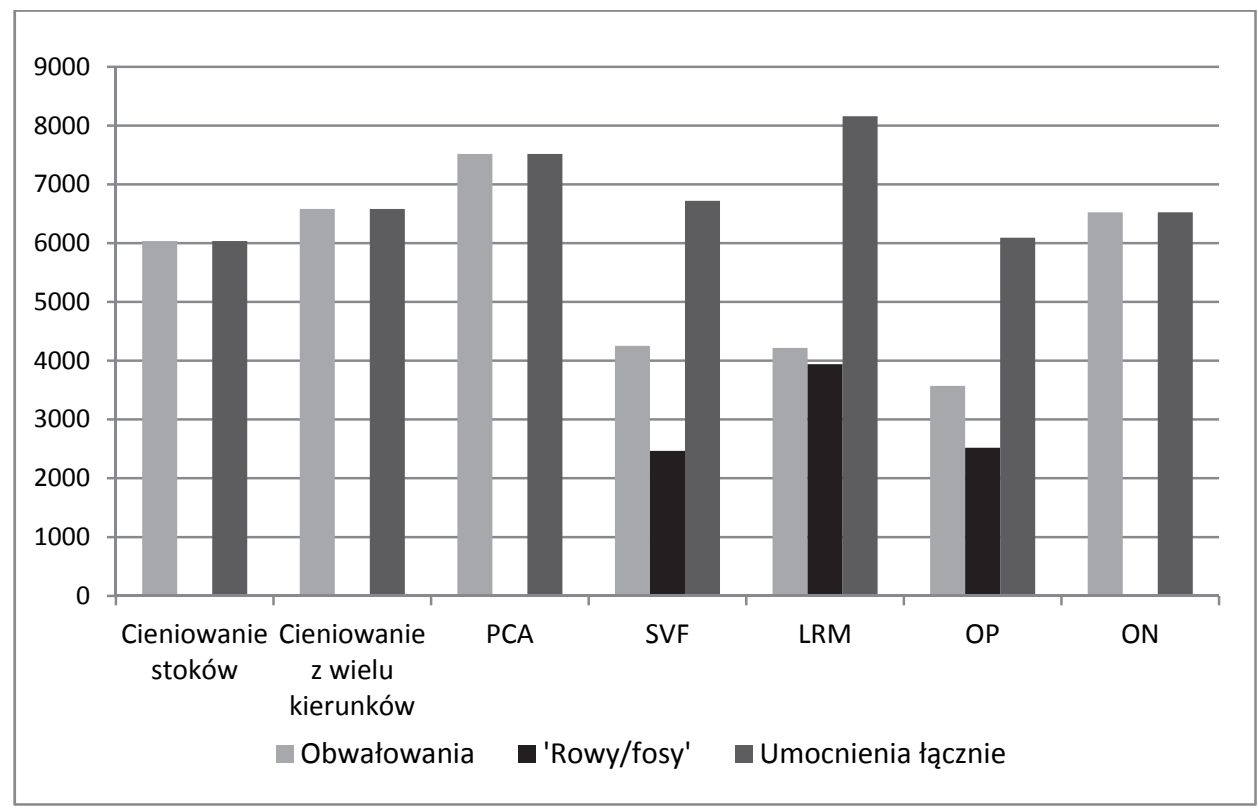

kanałów, co powoduje efekt „przesunięcia” obiektów i ich „rozmycia”. Podobny efekt, choć w ograniczonym zakresie, widoczny jest w analizie cieniowania $\mathrm{z}$ wielu kierunków, która także jest reprezentacją trzech kanałów przedstawionych na jednym obrazie. Należy zwrócić uwagę, że wyniki interpretacji analizy cieniowania $\mathrm{z}$ wielu kierunków i algorytmu $\mathrm{O}_{\mathrm{N}}$ dostarczyły bardzo podobnych wyników. W przypadku analizy cieniowania trudności w dokonaniu wektoryzacji i precyzyjnych pomiarów powierzchni obwałowań przysparzał „cień” na południowo-wschod- 
nich stokach wałów, który przesłaniał szczegóły ich mikrotopografii (południowo-wschodni stok i sąsiadujący z nim obszar był wyświetlany w ciemnych tonach). Analiza $\mathrm{O}_{\mathrm{P}}$ natomiast ze względu na metodę jej generowania zdecydowanie lepiej sprawdza się przy prezentowaniu obiektów wklęsłych niż wypukłych.

Oprócz detekcji obiektów zinterpretowanych jako obwałowania podczas obserwacji niektórych zobrazowań pojawiły się obiekty, które można byłoby uznać za pozostałości „rowów/fosy” zlokalizowanych wzdłuż nasypów. Jak wspomniano wcześniej, występowały one jedynie na trzech wizualizacjach $\left(\mathrm{O}_{\mathrm{P}}\right.$, LRM i SVF). Konfrontując te wyniki z profilami terenowymi, można przyjąć, że w każdym z tych przypadków nie mamy do czynienia z odwzorowaniem wklęsłego obiektu terenowego, a jedynie $\mathrm{z}$ artefaktami graficznymi, które zostały wytworzone przez owe algorytmy wizualizacyjne. Pozorna obecność „rowów/fosy” została wygenerowana przez takie oddanie stoków nasypów, które przypomina zagłębienia. Obiektów tych nie ma bowiem w pierwotnej chmurze punktów ani w numerycznym modelu terenu, ponieważ zostały „wytworzone” na etapie generowania wizualizacji. Oznacza to, że w omawianym przypadku nieuprawomocniony jest podział wyników interpretacji na obiekty związane z nasypami i ,rowami/fosą”. Zarówno jedne, jak i drugie odnoszą się bowiem do tych samych wypukłych form.

Na uwagę zasługuje także to, że, co prawda, w północno-zachodniej części grodziska, po zewnętrznej stronie wału, na odcinku mierzącym około 32 metry występuje podłużna niecka. Nie jest ona jednak pozostałością po fosie, a powstała w rezultacie erozji spowodowanej użytkowaniem przebiegającej w tym miejscu drogi gruntowej. Ta wklęsła forma nie została wzięta pod uwagę podczas naszych obliczeń.

W kontekście powyższych rozważań należy podkreślić, że uzyskane rezultaty nie przesądzają o tym, czy w pobliżu obwałowań wczesnośredniowiecznego grodziska znajdują się nawarstwienia związane z reliktami fosy, czy też ich nie ma. To, że pozostałości fosy nie manifestują się na powierzchni ziemi w postaci niecki uchwytnej na pochodnych lotniczego skanowania laserowego, nie jest okolicznością przesądzającą o ich istnieniu. Mogły bowiem zostać zniwelowane w przeszłości w wyniku prac polowych/leśnych lub jakość wykorzystanych w porównaniu danych oraz sposób ich przetworzenia nie pozwala na ich wyodrębnienie.

\section{Porównanie liczby zidentyfikowanych kurhanów}

Na obszarze A liczba nasypów (potencjalnych kurhanów) zinterpretowanych na poszczególnych wizualizacjach wynosiła: 3 - w przypadku analizy cieniowania, cieniowania z szesnastu kierunków i $\mathrm{O}_{\mathrm{N}}, 2$ - analiza głównych składowych (PCA) i SVF, 1 - $\mathrm{O}_{\mathrm{P}}, 0$ - LRM. Mniejsza liczba ujawnionych kurhanów przez analizę PCA może wynikać z efektu ,przesunięcia” form terenowych spowodowanego prezentacją kompozycji trzech kanałów (trzech składowych) na jednym obrazie, za pomocą różnych 
palet barwnych, o czym wspominaliśmy we wcześniejszej części artykułu. W konsekwencji powoduje to obniżenie kontrastu interpretowanego rastra i „rozmycie” niewielkich obiektów archeologicznych. Przypadek SVF potwierdza z kolei problematyczność działania tej wizualizacji w kontekście terenu o zróżnicowanej rzeźbie. Analiza $\mathrm{O}_{\mathrm{P}}$ nie wygenerowała wyraźnego kontrastu wokół domniemanych kurhanów (możliwego do zaobserwowania przy ustawieniach domyślnych wyświetlania rastra rozciągnięcie kontrastu do min./max. wartości rastra), ponieważ w tym przypadku mamy do czynienia z niewielkimi i silnie zniwelowanymi nasypami (obiekty wypukłe). Sugerując się jednak rezultatami z innych obrazowań (np. analiza cieniowania) możliwe jest w przypadku SVF i $\mathrm{O}_{\mathrm{P}}$ takie ustawienie zakresów wyświetlanych wartości rastrów, które pozwoli na częściowe ujawnienie niewidocznych wcześniej potencjalnych kurhanów. Po wprowadzeniu tych zmian jednak inne formy antropogeniczne z obszaru A staną się znacznie mniej czytelne lub przestaną być w ogóle widoczne.

W kontekście zaprezentowanego porównania zaskakującymi wydają się rezultaty uzyskane z pomocą algorytmu LRM, który w większości sytuacji dobrze się sprawdza przy ujawnianiu obiektów wypukłych, takich jak nasypy, kurhany itd. $\mathrm{W}$ omawianym przypadku nie pozwolił on jednak na ich wskazanie. Prowadzi to do wniosku, że należałoby jeszcze raz wykonać analizę LRM ze zmienionymi wartościami promienia wyszukiwania i maksymalnego zasięgu. Poprzez dostosowanie tych wartości do poziomu, który mógłby pozwolić na ujawnienie wspomnianych kurhanów, inne obiekty archeologiczne obecne na analizowanym obszarze mogłyby jednak ulec zniekształceniu lub stać się niewidoczne (np. „wygładzeniu” i częściowemu usunięciu uległyby obwałowania pobliskiego grodziska).

W tym kontekście należy podkreślić, że na obszarze B, o czym mowa w dalszej części artykułu, analiza LRM przeprowadzona przy takich samych ustawieniach okazała się bardzo skuteczna w zakresie ujawniania potencjalnych kurhanów. Rozbieżności w uzyskanych wynikach są spowodowane przez kontekst topograficzny, w którym znajdują się omawiane obiekty archeologiczne oraz przez ich rozmiar. Na obszarze A są one położone na kulminacji niewielkiego pagórka, co spowodowało, że nie zostały one odwzorowane, ponieważ algorytm LRM nadał komórkom rastra w tych miejscach wysokie wartości dodatnie. W konsekwencji „stopiły” się one ze swoim kontekstem topograficznym. Natomiast na obszarze B większość kurhanów położona jest w płaskim lub jedynie lekko pofałdowanym terenie, w związku z tym wizualizacja LRM pozwoliła na ich odwzorowanie. W kilku obserwowanych sytuacjach na obszarze B, gdzie na kulminacji niewielkich wyniesień inne wizualizacje pozwoliły na wskazanie hipotetycznych kurhanów, analogicznie jak w sytuacji zaobserwowanej na obszarze A, analiza LRM ich nie ujawniła. Można dlatego wysnuć konkluzję, że algorytm LRM ma obniżoną skuteczność ujawniania obiektów znajdujących się na kulminacjach i zboczach form terenowych, które są na tyle niewielkie, że nie zostały usunięte przez filtr dolnoprzepustowy, przez co występują w rastrze wynikowym jako obszary o wartościach dodatnich. 
Podobne rozbieżności w wektoryzacjach zinterpretowanych obiektów zaobserwowaliśmy na obszarze B, gdzie znajduje się rozległe cmentarzysko kurhanowe. Liczba potencjalnych zidentyfikowanych kurhanów wahała się od 88 (SVF) do $128\left(\mathrm{O}_{\mathrm{N}}\right)$ (tab. 2). W konfrontacji z profilami terenowymi oraz innymi wizualizacjami część ujawnionych kopców okazała się być artefaktami graficznymi (false positive) wygenerowanymi przez zastosowane algorytmy. Uwaga ta w szczególności dotyczy analizy $\mathrm{O}_{\mathrm{P}} \mathrm{i}$ LRM. Ponadto na wspomnianych dwóch zobrazowaniach w pobliżu wielu nasypów występowały „rowy dookolne”, które także były obiektami „dodanymi” przez algorytmy, a ich istnienia nie potwierdziły ani profile terenowe, ani pozostałe metody prezentowania danych ALS.

Spośród potencjalnych kurhanów zwektoryzowanych w obrębie obszaru B na wszystkich wygenerowanych wizualizacjach pokrywała się lokalizacja jedynie 69 . Zaprezentowana powyżej analiza charakterystyki przestrzennej cmentarzyska kurhanowego, mimo zastosowania szeregu zaawansowanych metod prezentacji danych ALS, nie pozwala nawet przesądzić o tym, jaka jest faktyczna liczba kurhanów występujących na obszarze B. Liczba 69 powtarzających się na wszystkich wizualizacjach obiektów nie może być uznana za wiążącą, ponieważ w dużej mierze jest ona pochodną działania analizy SVF i $\mathrm{O}_{\mathrm{P}}$, które mają znacznie mniejszy potencjał w ujawnianiu obiektów wypukłych niż pozostałe metody, dzięki którym zidentyfikowano najmniej obiektów (odpowiednio 88 i 93).

\section{Porównanie powierzchni kurhanów}

Omówione powyżej różnice w sposobie ujawniania się kurhanów w różnych wizualizacjach powodują również niemożność jednoznacznego określenia kształtów (ryc. 6) oraz powierzchni konkretnych obiektów (tab. 2). Dla porównania tej ostatniej wartości przeprowadzone zostały obliczenia ograniczone do wspomnianej wcześniej liczby 69 kurhanów. Zestawienie sum pól powierzchni zidentyfikowanych form terenowych pokazuje, że różnice między poszczególnymi zobrazowaniami są znaczne (wykres 4).

Zsumowana powierzchnia kurhanów, które powtarzały się na wszystkich pochodnych wynosiła od 4806,38 $\mathrm{m}^{2} \mathrm{w}$ przypadku SVF do 7343,23 $\mathrm{m}^{2}$ na zobrazowaniu PCA. Tym samym najniższa wartość stanowiła jedynie $65,4 \%$ maksymalnej. Ponadto należy podkreślić, że różnice między interpretacjami, które przyniosły dwie największe powierzchnie (PCA i analiza cieniowania) wynosiły jedynie 3,9\%, zaś pomiędzy najmniejszymi (SVF i LRM) 2,1\%.

Rozbieżności w zmierzonej powierzchni zinterpretowanych obiektów wskazują na to, choć ich lokalizacje pokrywały się w przestrzeni, to odwzorowane przez poszczególne algorytmy wizualizacyjne kształty, a także rozmiary były często całkowicie rozbieżne. Spostrzeżenie to powoduje konieczność refleksji nie tylko nad tym, 
jak stosowane przez archeologów metody prezentacji danych ALS wpływają na sposób reprezentowania stanowisk archeologicznych, lecz także jak bardzo odmienne może być przedstawienie tego samego obiektu na dwóch różnych pochodnych NMT.

Wykres 4. Porównanie pola powierzchni $\left(\mathrm{m}^{2}\right)$ zajmowanej przez kurhany zidentyfikowane na wszystkich wizualizacjach NMT na obszarze B (C G. Kiarszys, Ł. Banaszek)

Chart 4. Comparison of the total area $\left(\mathrm{m}^{2}\right)$ of all barrows interpreted from 8 different ALS visualizations within the area B (C G. Kiarszys, Ł. Banaszek)

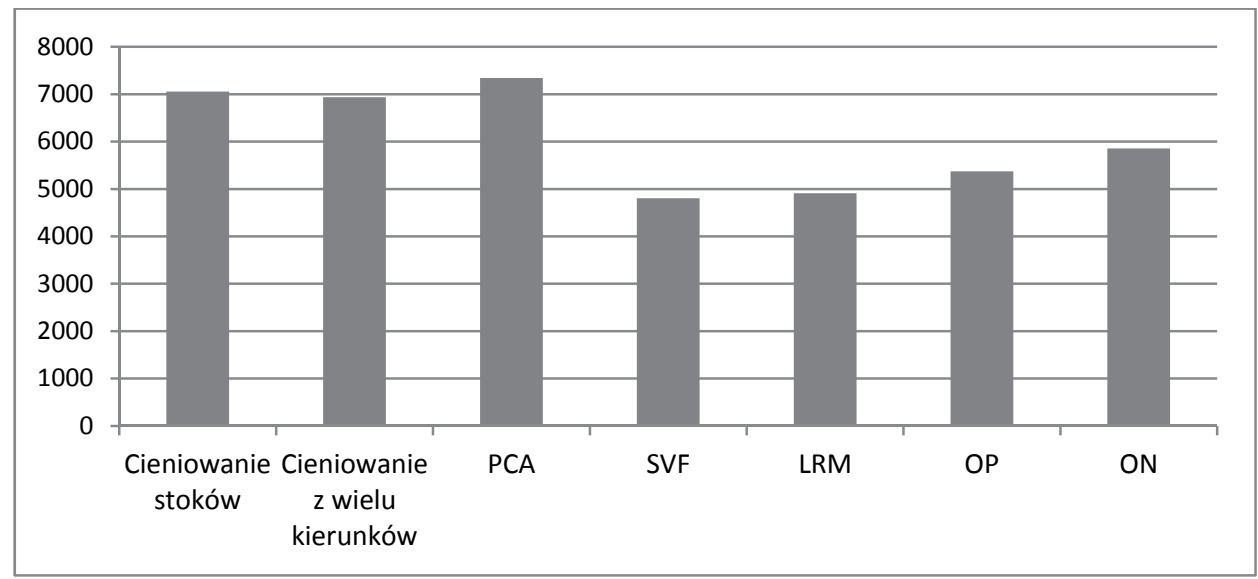

\section{WNIOSKI}

Każdy z etapów przetwarzania danych ALS związany jest z podejmowaniem arbitralnych decyzji, które mają wpływ na uzyskiwany efekt końcowy. Podczas analizy danych istotna jest także wiedza interpretatora i jego skuteczność w zakresie identyfikowania form terenowych, które mogą być uznane za potencjalne ślady działalności dawnych społeczności. Umiejętność ta nie ogranicza się jednak jedynie do wiedzy na temat różnych kategorii obiektów archeologicznych, ponieważ równie istotna jest $\mathrm{w}$ tym przypadku znajomość zasad działania wykorzystanych algorytmów wizualizacyjnych.

Jak staraliśmy się wykazać $\mathrm{w}$ niniejszym artykule, pochodne numerycznych modeli nie pozwalają na przedstawienie/odwzorowanie zarejestrowanego terenu w sposób realistyczny/obiektywny. Dlatego nie są one tak łatwe i intuicyjne w interpretacji, jak mogłoby się to wydawać. Ich zasady działania opierają się na selektywnej prezentacji pewnych aspektów topografii i eksponowaniu określonych jednych cech, kosztem innych. Plan stanowiska archeologicznego, który powstał na podstawie zestawienia obiektów zwektoryzowanych na podstawie różnych zobrazowań, może okazać się niespójny. Zarówno liczba zinterpretowanych obiektów, ich zasię- 
gi, lokalizacje oraz pola powierzchni będą różniły się między sobą w zależności od wykorzystanej metody wizualizacyjnej.

Wbrew temu, co może podpowiadać nam intuicja, najlepszej skuteczności w identyfikowaniu obiektów archeologicznych nie uzyskamy wcale, zestawiając wszystkie dostępne wizualizacje danego terenu i uznając za ,pewne” tylko te obiekty, które powtórzyły się na wszystkich z nich. Zawsze bowiem wówczas uzyskamy wynik, który będzie równy lub nawet gorszy od tego, co pokaże wizualizacja o najmniejszej skuteczności w prezentowaniu określonego typu obiektu. $\mathrm{Z}$ tego samego powodu algorytmy, które pozwalają na zarejestrowanie największej liczby określonej kategorii obiektów archeologicznych lub ich największej powierzchni, wcale nie mogą być uznawane za najskuteczniejsze.

W tym kontekście znacznie lepsze rezultaty daje świadoma interpretacja, odwołująca się do wiedzy na temat potencjału i ograniczeń wykorzystanych algorytmów. Pozwala ona bowiem na skuteczne konfrontowanie różnych zobrazowań, a w określonych okolicznościach, także na wskazanie artefaktów graficznych (false positive) i innych błędów powstałych podczas przetwarzania danych. Przydatnym narzędziem weryfikacji są także profilowania wykonywane na numerycznych modelach, które $\mathrm{w}$ zestawieniu z obiektami widocznymi na ich pochodnych pozwalają z dużym prawdopodobieństwem wskazać na to, czy mamy do czynienia $\mathrm{z}$ formą, która była obecna w pierwotnym modelu, czy też została ona dopiero „dodana” na etapie generowania wizualizacji.

\section{BIBLIOGRAFIA}

Banaszek Ł.

2014 Lotniczy skaning laserowy w polskiej archeologii. Czy w pełni wykorzystywany jest potencjał prospekcyjny metody? Folia Praehistorica Posnaniensia, 19, s. 207-251.

2015 Przeszte krajobrazy w chmurze punktów. Poznań: Wydawnictwo Naukowe UAM.

Banaszek Ł., Bartkowiak R., Błażejewska M., Skrzeczyńska M.

2018 Lotnicze skanowanie laserowe: wyzwanie konserwatorskie. W: M. Gojda, Z. Kobyliński (red.), Archaeologica Hereditas, T. 11, Lotnicze skanowanie laserowe jako narzędzie archeologii (s. 189-203). Warszawa: Fundacja Res Publica Multiethnica.

Barthes R.

2008 Światto obrazu. Uwagi o fotografii. Warszawa: Wydawnictwo Aletheia.

Bennett R., Welham K., Hill R. A., Ford A.

2012 A Comparison of Visualisation Techniques for Models Created from Airborne Laser Scanned Data. Archaeological Prospection, 19, s. 41-48.

Berkeley G.

1709 An Essay Towards a New Theory of Vision. Dublin: Jeremy Pepyat.

Blinn J. F.

1977 Models of light reflection for computer synthesized pictures. SIGGRAPH Computer Graphics, 11(2), s. 192-198. 
Borkowski A.

2014 Numeryczne modele wysokościowe i produkty pochodne. W: P. Wężyk (red.), Podręcznik dla uczestników szkoleń z wykorzystania produktów LiDAR (s. 110-131). Warszawa: Główny Urząd Geodezji i Kartografii.

Challis K., Forlin P., Kincey M.

2011 A Generic Toolkit for the Visualization of Archaeological Features on Airborne LiDAR Elevation Data. Archaeological Prospection, 18(4), s. 279-289.

Cowley D. C., Opitz R. S.

2013 Interpreting archaeological topography: lasers, 3D data, observations, visualization and applications. W: R. S. Opitz, D.C. Cowley (red.), Interpreting archaeological topography, airborne laser scanning, 3D data and ground observation (s. 1-12). Oxford and Oakville: Oxbow Books.

Crutchley S. P.

2006 Lidar in the Witham Valley, Lincolnshire: an assessment of new remote sensing techniques. Archaeological Prospection, 13, s. 251-257.

Crutchley S., Crow P.

2009 The Light Fantastic: Using airborne laser scanning in archaeological survey. Swindon: English Heritage.

Denbigh K. G.

1979 Świat i czas. Warszawa: PWN.

Devereux B. J., Amable G. S., Crow P.

2008 Visualisation of LiDAR terrain models for archaeological feature detection. Antiquity, 82, s. $470-479$.

Doneus M.

2013 Openness as Visualization Technique for Interpretative Mapping of Airborne Lidar Digital Terrain Models. Remote Sensing, 5, s. 6427-6442.

Doneus M., Kühteiber T.

2013 Airborne laser scanning and archaeological interpretation - bringing back the people. W: R. S. Opitz, D.C. Cowley (red.), Interpreting archaeological topography, airborne laser scanning, 3D data and ground observation (s. 32-50). Oxford and Oakville: Oxbow Books.

Foucault M.

1980 Power/Knowledge. Selected Interviews and Other Writings 1972-1977. Brighton: Pantheon Books.

Gosden C.

1994 Social being and time. Oxford-Cambridge: Blackwell.

Gotlib D., Iwaniak A., Olszewski R.

2007 GIS. Obszary zastosowań. Warszawa: Wydawnictwo Naukowe PWN.

Hall E. T.

1978 Ukryty wymiar. Warszawa: PIW.

Haugerund R., Harding D. J.

2001 Some Algorithms for Virtual Deforestation (VDF) of Lidar Topographic Survey Data. International Archives of Photogrammetry and Remote Sensing, 34(3), 211-217.

Hesse R.

2010 LiDAR-derived Local Relief Models - a new tool for archaeological prospection. Archaeological Prospection, 17(2), s. 67-72.

2016 Visualisierung hochauflösender digitaler Geländemodelle mit LiVT. W: U. Lieberwirth, I. Herzog (red.), Computeranwendungen und Quantitative Methoden in der Archäologie. 
4. Workshop Der AG CAA 2013, Edition Topoi, Berlin Studies of the Ancient World (s. 109-128). Berlin: Topoi.

Horn B. K. P.

1981 Hill shading and the reflectance map. Proceedings of the IEEE, 69(1), 14-47.

Khosravipour A., Skidmore A. K., Isenburg M., Wang T. J.

2015 Development of an algorithm to generate pit-free Digital Surface Models from LiDAR. Proceedings of SilviLaser 2015, September 2015, s. 247-249.

Kiarszys G., Szalast G.

2014 Archeologia w chmurze punktów. Porównanie rezultatów filtracji i klasyfikacji gruntu w projekcie ISOK z wynikami opracowanymi w oprogramowaniu LAStools i Terrasolid. Folia Praehistorica Posnaniensia, 19, s. 267-292.

Kokalj Ž., Zakšek K., Oštir K.

2011 Application of sky-view factor for the visualization of historic landscape features in lidar-derived relief models. Antiquity, 85, s. 263-273.

Kokalj Ž., Zakšek K., Oštir K.,

2013 Visualizations of lidar derived relief models. W: R. S. Opitz, D. C. Cowley (red.), Interpreting archaeological topography, airborne laser scanning, 3D data and ground observation (s. 100-114). Oxford and Oakville: Oxbow Books.

Kolalj Ž., Hesse R.,

2017 Airborne laser scanning raster data visualisation: A guide to good practice. Ljubljana: Založba ZRC.

Korzeniowska K., Łącka M.

2011 Generating DEM from LiDAR data - comparison of available software tools. Archiwum Fotogrametrii, Kartografii i Teledetekcji, 22, s. 271-284.

Kraus K., Pfeifer N.

1998 Determination of terrain models in wooded areas with airborne laser scanner data. ISPRS Journal of Photogrammetry and Remote Sensing, 53, 193-203.

2001 Advanced DTM generation from LiDAR data. International Archives of Photogrammetry, Remote Sensing and Spatial Information Sciences, 34/3, s. 23-30.

Królikowski J.

2012 ISOK od kuchni. Geodeta, 7, s. 19-22.

Kurczyński Z.

2014 Lotnicze skanowanie laserowe - podstawy teoretyczne. W: P. Wężyk (red.), Podręcznik dla uczestników szkoleń z wykorzystania produktów LiDAR (s. 59-84). Warszawa: Główny Urząd Geodezji i Kartografii.

Łosiński W.

1957 Badania powierzchniowe w dorzeczu Regi i Parsęty. Materiaty Zachodniopomorskie, 3, s. $175-188$.

1973 Wczesnośredniowieczny zespół osadniczy w Bardach i Świelubiu pod Kołobrzegiem. Koszalińskie Zeszyty Muzealne, 3, s. 102-119.

Mara H., Krömker S., Breuckmann J. S.

2010 GigaMesh and Gilgamesh - 3D Multiscale Integral Invariant Cuneiform Character Extraction. W: A. Artusi, M. Joly, G. Lucet, A. Ribes, D. Pitzalis (red.), VAST'10 Proceedings of the 11th International Symposium on Virtual Reality, Archaeology and Cultural Heritage (s. 131-138). Aire-la-Ville: Eurographics Association.

Maślanka M., Wężyk P.

2014 Projekt ISOK - geneza i cel realizacji. W: P. Wężyk (red.), Podręcznik dla uczestników szkoleń z wykorzystania produktów LiDAR (s. 12-21). Warszawa: Główny Urząd Geodezji i Kartografii. 
Merleau-Ponty M.

2001 Fenomenologia percepcji. Warszawa: Wydawnictwo Aletheia.

Michalik T.

2014 Between the eye and the mind. Technology, cognition and knowledge development eye-tracking study report. AARGnews, 48, s. 24-34.

Miller G.

1994 Efficient Algorithms for Local and Global Accessibility Shading, Proceedings of the 21th Annual Conference on Computer Graphics and Interactive Techniques, SIGGRAPH 1994, 319-326.

Olczak W., Siuchniński K.

1970 Źródta archeologiczne do studiów nad wczesnośredniowiecznym osadnictwem grodowym na terenie województwa koszalińskiego (T. 3). Poznań: Uniwersytet im. Adama Mickiewicza.

Opitz R. S.

2013 An overview of airborne and terrestrial laser scanning in archaeology. W: R. S. Opitz, D. C. Cowley (red.), Interpreting archaeological topography, airborne laser scanning, $3 D$ data and ground observation (s. 13-31). Oxford and Oakville: Oxbow Books.

Palmer R.

2013 Reading aerial images. W: R. S. Opitz, D. C. Cowley (red.), Interpreting archaeological topography, airborne laser scanning, 3D data and ground observation (s. 76-87). Oxford and Oakville: Oxbow Books.

Pałubicka A., Tabaczyński S.

1986 Społeczeństwo i kultura jako przedmiot badań archeologicznych. W: W. Hensel, G. Donato, S. Tabaczyński (red.), Teoria i praktyka badań archeologicznych, T. 1: Przestanki metodologiczne (s. 57-183). Wrocław: Ossolineum.

Phong B. T.

1975 Illumination for Computer Generated Pictures. Communications of the ACM, 18(6), s. $311-317$.

Rączkowski W.

2002 Archeologia lotnicza - metoda wobec teorii. Poznań: Wydawnictwo Naukowe UAM.

2004 Przeszłość uchwycona? Kilka refleksji nad fotografią i badaniem przeszłości. W: Pałubicka A., Dobosz A. (red.), Umyst i kultura: zbiór rozpraw (s. 147-158). Bydgoszcz: Oficyna Wydawnicza Epigram.

2012 Metody w archeologii. W: S. Tabaczyński, A. Marciniak, D. Cyngot, A. Zalewska (red.), Przeszłość społeczna. Próba konceptualizacji (s. 367-406). Poznań: Wydawnictwo Poznańskie.

Reitberger J., Krzystek P., Stilla U.

2008 Analysis of full waveform LIDAR data for the classification of deciduous and coniferous tress. International Journal of Remote Sensing, 29(5), s. 1407-1431.

Robinson D.

2006 Urban morphology and indicators of radian availability. Solar Energy, 80(12), s. 16431648.

Rusinkiewicz S., Burns M., DeCarlo D.

2006 Exaggerated shading for depicting shape and detail. ACM Transactions on Graphics, 25(3), s. 1199-1205.

Szadkowski A.

2012 ISOK - co znajdziemy w zasobie? Geodeta, 7, s. 14-18. 
Wężyk P.

2006 Wprowadzenie do technologii skaningu laserowego w leśnictwie. Rocznik Geomatyki, 4/4, s. $119-132$.

Wężyk P. (red.)

2014. Podręcznik dla uczestników szkoleń z wykorzystania produktów LiDAR. Warszawa: Główny Urząd Geodezji i Kartografii.

Yard M. D., Bennett G. E., Mietz S. N., Coggins Jr. L. G., Stevens L. E., Hueftle S., Blinn D. W.

2005 Influence of topographic complexity and solar insolation estimates for the Colorado River, Grand Canyon, AZ. Ecological Modelling, 183(2-3), s. 157-172.

Yoëli P.

1965 Analytische Schattierung. Ein kartographischer Entwurf. Kartographische Nach-richten, 15(5), s. 141-148.

Yokoyama R., Shirasawa M., Pike R. J.

2002 Visualizing topography by openness: A new appli-cation of image processing to digital elevation models. Photogrammetric Engineering and Remote Sensing, 68, s. 257-265.

Zakšek K., Pfeifer N.

2006 An improved morphological filter for selecting relief points from a lidar point cloud in steep areas with dense vegetation. Delft: Delft Institute of Earth Observation and Space Systems.

\title{
TO IDENTIFY AND UNDERSTAND. A COMPARISON OF SELECTED ALS VISUALIZA- TION TECHNIQUES USED IN ARCHAEOLOGICAL INTERPRETATIVE MAPPING
}

\author{
S u m m a r y
}

The world we dwell in is constituted by cultural meanings and symbols. Knowledge plays essential role in understanding of stimuli through the senses. It is used for ordering and attributing meanings to our experiences. Without knowledge, the reality would forfeit its reason by turning into incoherent stream of stimuli.

The very same mechanism can be observed in everyday life, in the formalized and strictly controlled steps of scientific research as well as while experiencing works of art. For that reason, it is omnipresent in the interpretation of manifold visualizations derived from the remotely acquired data or other types of archaeological documentation. The reception of every visual communicate is dictated by knowledge possessed by the interpreter, his/her earlier experiences, emotions, or language. According to E. Husserl, human perception is always intentional and refers to cultural conventions. Thus, no less important is the aim of the undertaken interpretation and established perspective. Therefore, the cultural codes are shaped due to a certain historical circumstances, and, as a result, knowledge created through them is historical in its character.

Archaeology has benefited from the application of airborne laser scanning (ALS). The method serves for many purposes, amongst which the identification of relief features is fundamental. However, unless the detection is automated, the recognition of archaeological objects in the observed dataset is bounded by the interaction between human mind, eye, and the visual phenomena 
that are displayed on the screen. To improve effectiveness of ALS interpretation several visualization techniques have been developed. Yet, due to their complexity, the spatial information produced by these algorithms differs.

In this paper, we discuss some issues related to the application of different visualization techniques that are used commonly by archaeologists to identify and interpret relief features. Amongst many visualization algorithms available, we selected several: analytical hillshading, hillshading from multiple directions, Sky-view Factor, Local Relief Model, Openness, and Principal Component Analysis. The national lidar dataset collected by Polish government for the purposes of the IT System for Country's Protection against Extreme Hazards (ISOK) was used to present the subjectivism and ambiguity of digital products derived from the ALS data. The area of Bardy and Świelubie (commune Dygowo, Western Pomerania Voivodeship) was chosen to serve as a case study due to its complex topography and abundance of manifold anthropogenic landforms.

Here, we evaluate selected presentation techniques and compare the outputs of the interpretative mapping that was performed for each visualisation separately. We argue that the relationship between knowledge about the method and the technical principles of the applied visualisation algorithms as well as the understanding of objects observed on the generated images have great impact on the results of interpretation. The discrepancies between selected visualisation techniques used for archaeological purposes are being discussed. Unlike previous attempts, the presented comparison is based on vector outputs of the interpretative mapping. We demonstrate in detail the differences in the morphology as well as quantity of the identified archaeological features due to the use of particular visualization techniques. However, we discuss solely the formal characteristics of archaeological objects identified in ALS derivatives. We deal neither with the matter of the deep interpretation nor with the creation of narrative about the Past. 